Article ID: 8933

DOI: $10.5586 /$ asbp. 8933

Publication History

Received: 2020-01-08

Accepted: 2020-07-03

Published: 2020-10-08

Handling Editor

Agnieszka Popiela, University of

Szczecin, Poland;

https://orcid.org/0000-0001-

9297-0538

\section{Authors' Contributions}

PB and AW conceived and designed the analysis, performed

molecular analyses, and

interpreted the data; BB

contributed to data analysis tools;

JM performed the statistical

analyses and drafted the

manuscript

\section{Funding}

This work was funded by a KBN/NCN grant (N303 814440) to JM.

\section{Competing Interests}

No competing interests have been declared.

\section{Copyright Notice}

(c) The Author(s) 2020. This is an open access article distributed under the terms of the Creative Commons Attribution License, which permits redistribution, commercial and noncommercial, provided that the article is properly cited.
ORIGINAL RESEARCH PAPER in RECENT DEVELOPMENTS IN TAXONOMY AND PHYLOGENY OF PLANTS

\section{Phylogeny of Aconitum Subgenus Aconitum in Europe}

\author{
Piotr Boroń (iD) ${ }^{1}$, Ada Wróblewska $\mathbb{1}^{2}$, Bogusław Binkiewicz $\mathbb{1}^{3}$, \\ Józef Mitka ${ }^{3 *}$ \\ ${ }^{1}$ Department of Forest Pathology, Mycology and Tree Physiology, University of Agriculture in \\ Krakow, 29 Listopada 46, Kraków, 31-425, Poland \\ ${ }^{2}$ Institute of Biology, Faculty Biology and Chemistry, University of Bialystok, Ciołkowskiego \\ 1J, Białystok, 15-245, Poland \\ ${ }^{3}$ Botanical Garden, Institute of Botany, Jagiellonian University in Kraków, Kraków, 31-501, \\ Poland \\ *To whom correspondence should be addressed. Email: j.mitka@uj.edu.p
}

\begin{abstract}
Phylogenetic relations within Aconitum subgen. Aconitum (Ranunculaceae) in Europe are still unclear. To infer the phylogeny of the nuclear (ITS) region and chloroplast intergenic spacer $t r n \mathrm{~L}^{(\mathrm{UAG})}-n d h \mathrm{~F}$ of the chloroplast DNA (cpDNA), we analyzed 64 accessions within this taxon, 58 from Europe and six from the Caucasus Mts. Nuclear ITS sequences were identical in 51 European and two Caucasian accessions, whereas the remaining sequences were unique. cpDNA sequences could be categorized into five haplotypes, i.e., $A-E$, including a European-Caucasian Aconitum haplotype $B$. Ten cpDNA sequences were unique. A 5-bp indel distinguished the diploids from the tetraploids. None of the extant European diploids were basal to the tetraploid local group. A phylogenetic tree based on combined ITS and cpDNA sequences (bayesian inference, maximum likelihood, minimal parsimony) placed Aconitum burnatii (Maritime Alps, Massif Central) and $A$. nevadense (Sierra Nevada, Pyrenees) in a sister group to all other European species. A Bayesian relaxed clock model estimated the earliest split of the Caucasian species during the Late Miocene [ca. 7 million years ago (Mya)], and the divergence of $A$. burnatii and $A$. nevadense from the European genetic stock during the Miocene/Pliocene (ca. 4.4 Mya). Diploids in Europe are likely to be descendants of the Miocene European-Caucasian flora linked with the ancient Asian (arctiotertiary) genetic stock. The origins of the tetraploids remain unclear, and it is possible that some tetraploids originated from local, now extinct diploids. Both the diploids and tetraploids underwent rapid differentiation in the Late Pliocene - Quaternary period.
\end{abstract}

\section{Keywords}

Aconitum; Caucasus Mts; Europe; ITS; molecular clock; phylogeny; trnL ${ }^{(\mathrm{UAG})}$ $n d h \mathrm{~F}$

\section{Introduction}

The family Ranunculaceae is one of the earliest diverging lineages among the eudicots (Stevens, 2001), and might have radiated within Ranunculales 121-114 million years ago (Mya) (Anderson et al., 2005), or as early as 125.8-123.0 Mya, as proposed by the "accelerated angiosperm evolution" hypothesis (W. Wang et al., 2016). In Ranunculales, additional evidence from phylogenetic analyses of MADS-box genes supports whole-genome duplication early in the diversification of angiosperms (Landis et al., 2018; Tank et al., 2015). The split between Aconitum and other genera occurred 24.7 Mya (Park et al., 2020), the divergence between Aconitum L. subgen. Aconitum and subgen. Lycoctonum (DC.) Peterm. has been 
dated to have occurred approximately 8.24-20.7 Mya (L. Wang et al., 2009), and lastly, Aconitum subgen. Aconitum began to radiate between 2.5 and 6.4 Mya (L. Wang et al., 2009).

Aconitum and Delphinium L., the latter including Consolida Gray, Aconitella Spach, and Staphisagria J. Hill, form the monophyletic tribe Delphinieae Schröd., subtribe Delphiniinae Benth. \& Hook (Jabbour \& Renner, 2011a; Keener et al., 1999; M. Tamura, 1993; Turland \& Barrie, 2001; W. Wang et al., 2009). Zygomorphic flowers and presence of diterpene alkaloids have been identified as synapomorphies within this taxonomic group (Jabbour et al., 2009; Johansson, 1995). Aconitum consists of the following subgenera: subgen. Aconitum, subgen. Fletcherum (Tamura) Y. Hong \& Q. E. Yang, subgen. Galeata (Rapaics) Y. Hong \& Q. E. Yang, and subgen. Lycoctonum (Hong et al., 2017; Jabbour \& Renner, 2011b; Kita et al., 1995; Luo et al., 2005; Utelli et al., 2000). The taxonomic rank of subgen. Anthora (Rapaics) Peterm. is unclear and requires further investigation (Novikoff \& Mitka, 2015).

The genus Aconitum (monkshood) consists of ca. 300 species distributed across the temperate regions of the Northern Hemisphere, with a center of diversification recognized in Eastern Asia (Himalaya, Southwestern China, and Japan) (Kadota, 1987; Liangqian \& Kadota, 2001; Luo et al., 2005). The subgenus Aconitum includes more than 250 species, of which 22 native species (excluding numerous hybrid species) can be found in Europe, a secondary center of Aconitum diversification (Table 1) (Götz, 1967; Mitka, 2003; Mitka \& Starmühler, 2000; Novikoff \& Mitka, 2011, 2015; Novikoff et al., 2016; Seitz, 1969; Starmühler \& Mitka, 2001). Recently, efforts have been made to clarify the taxonomic sectional divisions of subgenus Aconitum in the Carpathian Mts, using cytogenetic criteria (see Table 1) (Ilnicki \& Mitka, 2009, 2011; Joachimiak et al., 1999; Mitka et al., 2007). Eight species belonging to this subgenus occur exclusively in the Carpathian and Balkans Mts.

Phylogenetic relationships within A. subgen. Aconitum in Europe have not yet been analyzed and remain unknown. Only a few European accessions were included in a genus-wide phylogenetic study, namely $A$. napellus L. and A. variegatum L. (Luo et al., 2005). Jabbour \& Renner (2011b) and Xiang et al. (2017) estimated a split between the European accessions A. pentheri Hayek and A. napellus L. to have occurred ca. 0.9 Mya. Thus, very few European accessions were examined, and insufficient geographical sampling did not allow any relevant interpretation. Aconitum L. subgen. Aconitum is known for its high morphological plasticity and extensive interspecific hybridization (Kita \& Ito, 2000; Krzakowa \& Szweykowski, 1976; Sutkowska et al., 2013; Sutkowska, Boroń, et al., 2017; Sutkowska, Warzecha, \& Mitka, 2017; Zieliński, 1982a, 1982b), and the latter is considered to be a major cause of taxonomic unclarity (Kadota, 1981; Tutin et al., 1993). Various Aconitum species have been found to possess identical chloroplast DNA (cpDNA) sequences, resulting from horizontal gene transfer (Kita \& Ito, 2000; Kita et al., 1995; Luo et al., 2005; Utelli et al., 2000). In particular, Aconitum species may contain multiple versions of the nuclear-encoded plastid genes (e.g., rpl32 paralogs), thus exhibiting phylogenetic incongruence (Park et al., 2020).

In a preliminary study, we found two cpDNA haplotypes in A. subgen. Aconitum from the Carpathian Mts that generally fit the cytogenetic (diploids vs. tetraploids) and taxonomic sectional division (sect. Cammarum vs. sect. Aconitum) (see Mitka et al., 2016) criteria.

Here, we aimed to resolve the complicated genetic relationships among the Aconitum taxa throughout its European range, using plastid (cpDNA) and nuclear DNA (internal transcribed spacer, ITS) sequences of species distributed across Western, Central, and Southern Europe, and in the Caucasus Mts. The primary purpose of our phylogenetic analyses was to demonstrate the relationships between the studied species and regions; thus, the pattern of clades retrieved here should not be used solely as a justification for taxonomic decisions (Hörandl, 2006).

Taking the differences in the cytogenetic and ecological profiles of the European and Caucasian Aconitum into consideration, we attempted to determine if: (i) 
Table 1 Sectional divisions of Aconitum subgen. Aconitum in Europe (Mitka et al., 2017).

\begin{tabular}{|c|c|}
\hline \multirow{13}{*}{$\begin{array}{l}\text { Aconitum } \text { L. sectio Aconitum } \\
\text { subsectio Aconitum }(2 n=32)\end{array}$} & Series Aconitum \\
\hline & Aconitum anglicum Stapf \\
\hline & Aconitum bucovinense Zapał. \\
\hline & Aconitum corsicum Gáyer \\
\hline & Aconitum firmum Rchb. \\
\hline & Aconitum napellus L. \\
\hline & Aconitum plicatum Rchb. \\
\hline & Aconitum superbum Fritsch \\
\hline & Series Castellana Rottenst. \\
\hline & Aconitum castellanum (Molero \& Blanché) Rottenst. \\
\hline & Series Taurica Mucher ex Starm. \\
\hline & Aconitum clusianum Rchb. \\
\hline & Aconitum tauricum Wulfen \\
\hline \multirow{4}{*}{$\begin{array}{l}\text { Aconitum L. sectio Aconitum } \\
\text { subsectio Burnatii Rottenst. ( } 2 n \\
=32 \text { ) }\end{array}$} & Aconitum burnatii Gáyer \\
\hline & Aconitum maninense (Skalický) Mitka \\
\hline & Aconitum nevadense Gáyer \\
\hline & Aconitum pentheri Hayek \\
\hline \multirow{9}{*}{$\begin{array}{l}\text { Aconitum L. sectio Cammarum } \\
\text { DC. subsectio Cammarum (DC.) } \\
\text { Rapaics }(2 n=16)\end{array}$} & Series Variegata Steinberg ex Starm. \\
\hline & Aconitum variegatum $\mathrm{L}$. \\
\hline & Aconitum vitosanum Gáyer \\
\hline & Aconitum vivantii Rottenst. \\
\hline & Series Toxicum (Rchb.) Mucher \\
\hline & Aconitum degenii Gáyer \\
\hline & Aconitum lasiocarpum (Rchb.) Gáyer \\
\hline & Aconitum pilipes (Rchb.) Gáyer \\
\hline & Aconitum toxicum Rchb. \\
\hline $\begin{array}{l}\text { Aconitum sectio Angustifolium } \\
\text { (Seitz) Rottenst. }(2 n=48)\end{array}$ & Aconitum angustifolium Rchb. \\
\hline
\end{tabular}

the European tetraploids originated in situ from the diploid genetic stock, and (ii) genetic signatures exclusive to diploid and tetraploid species exist, using phylogenetic analyses based on ITS and cpDNA sequences ( $\operatorname{trn} \mathrm{L}^{(\mathrm{UAG})}-n d h \mathrm{~F}$ region).

\section{Material and Methods}

\subsection{The Study Taxon}

The subgenus Aconitum L. in Europe consists of the (i) tetraploid sect. Aconitum $[2 n(4 x)=32]$, (ii) diploid sect. Cammarum DC. [ $2 n(2 x)=16]$, (iii) monospecific sect. Angustifolium (Seitz) Rottensteiner, represented by allopolyploid $A$. angustifolium Rchb. [ $2 n(6 x)=48]$, and (iv) triploid nothosect. Acomarum Starm. $[2 n(3 x)=24]$. Sect. Aconitum consists of subsect. Aconitum and subsect. Burnatii Rottensteiner, with the latter possessing a glandular indumentum, which is unusual within the tetraploids (Table 1) (Starmühler \& Mitka, 2001). In Europe, 10 species belonging to sect. Aconitum, seven to sect. Cammarum, and one to sect. Angustifolium have been noted (Table 1). Intersectional hybrids (A. sect. Aconitum $\times$ A. sect. Cammarum) are circumscribed within the nothosect. Acomarum Starm., and consist of seven nothospecies and three hybrid formulae (Starmühler, 2001; Wacławska-Ćwiertnia \& Mitka, 2016).

The tetraploid Aconitum sect. Aconitum encompasses high-mountain species of the subalpine and alpine zones (Table 1) (Ilnicki \& Mitka, 2009; Mitka, 2000, 2002; Novikoff \& Mitka, 2011; Seitz, 1969; Sutkowska, Warzecha, \& Mitka, 2017). The diploid A. sect. Cammarum includes lowland and montane species (up to ca. 1,150 m above sea level) growing in forest environments (Ilnicki \& Mitka, 2011; Joachimiak et al., 1999; Mitka, 2003). 
The chromosome numbers were investigated using specimens from the Carpathian and Sudetes Mts (Ilnicki \& Mitka, 2009, 2011; Joachimiak et al., 1999; Mitka et al., 2007), or obtained from the on-line DCBD database (Simon et al., 1999), which is a conspect of chromosome numbers in the tribe Delphinieae (Bosch et al., 2016).

Both these sections (diploids and tetraploids) differ in their nuclear 2C DNA contents (ca. 11 pg vs. 21-22 pg, respectively) (Joachimiak et al., 2018).

\subsection{Taxon Sampling}

The present study included 64 accessions representing A. subgen. Aconitum in Europe, all of which were sequenced for the first in this study. These accessions were as follows: sect. Cammarum: A. degenii Gáyerssp. degenii (one accession), A. d. ssp. intermedium (Zapał.) Mitka (one), A. d. ssp. paniculatum (Arcang.) Mucher (two), A. d. ssp. rhaeticum Starm. (one), A. ×hebegynum DC. (A. degenii $\times$ A. variegatum) (one), A. lasiocarpum Rchb. ssp. kotulae (Pawł.) Starm. \& Mitka (one), A. l. ssp. lasiocarpum (one), A. ×pawlowskii Mitka \& Starm. (A. lasiocarpum $\times$ A. variegatum) (three), A. toxicum Rchb. spp. toxicum (four), A. pilipes (Rchb.) Gáyer (two), A.variegatum L. ssp. nasutum (Rchb.) Götz (four), A. v. ssp. variegatum (two), A. vitosanum (one); sect. Aconitum: A. anglicum Stapf (one), A. bucovinense Zapał. (four), A. burnatii Gáyer (one), A. ×czarnohorense (Zapał.) Mitka (A. bucovinense $\times$ A. $\times$ nanum) (one), A. firmum Rchb. ssp. firmum (one), A.f. ssp. fissurae (two), $A$. f. ssp. moravicum Skalický (one), A. maninense (Skalický) Mitka (three), A. ×nanum (Baumg.) Simonk. (A. bucovinense $\times$ A. firmum) (one), A. napellus Rchb. ssp. napellus (one), A. nevadense Gáyer (one), A. pentheri Hayek (two), A. plicatum Rchb. ssp. plicatum (two), A. p. ssp. sudeticum Mitka (four), A. superbum Fritsch (one), A. tauricum Wulfen (one); Nothosect. Acomarum: A. $\times$ cammarum L. em. Fries $(A$. napellus $\times$ A. variegatum), A. $\times$ berdaui Zapal. (A. firmum $\times$ A. variegatum).

The Caucasian stock (Luferov, 2000) was represented by A. cymbulatum (Schmalh.) Lipsky (one accession), A. nasutum Fisch. ex Rchb. (four), and A. pubiceps Rupr. (one). In total, 27 taxa (species, subspecies, and nothospecies) from the Pyrenees, Alps, Sudetes, Carpathians, and Balkans were included, covering most of the taxonomic variability of $A$. subgen. Aconitum in Europe (Figure 1, Table S1).

Two accessions from A. subgen. Lycoctonum, i.e., A. lycoctonum L. em. Koelle and A. moldavicum Hacq. (Kita et al., 1995) constituted the outgroup.

\subsection{DNA Extraction, Amplification, and Sequencing}

Recently collected samples (stored as silica-dried leaves) or herbarium specimens of all accessions were obtained (Table S1). Samples for DNA extraction were prepared from these materials, using ca. $2 \mathrm{~cm}^{2}$ of the fully developed leaf blade with no symptoms of damage due to insects or fungal infections. Samples were ground in $2 \mathrm{~mL}$ microcentrifuge tubes with three stainless steel beads $(\varphi 3 \mathrm{~mm}$ ) by shaking in an oscillation mill (MM 200-Retsch, Germany) for 4 min at $25 \mathrm{~Hz}$. DNA was then extracted separately for each sample with Genomic Mini AX Plant DNA extraction kit (A\&A Biotechnology, Poland), according to the manufacturer's protocol.

Two target fragments were used for phylogenetic reconstruction: a fragment of the maternally inherited cpDNA separating plastid $\operatorname{trn} \mathrm{L}^{(\mathrm{UAG})}$ and $n d h \mathrm{~F}$ genes (positioned between sites 115,891 and 114,942 relative to the A. kusnezoffii complete plastid genome), and the biparentally inherited ITS region of the ribosomal RNA gene cluster, a tested marker in Aconitum allowing resolution of the infrageneric phylogeny within the genus (Jabbour \& Renner, 2011b; Kita \& Ito, 2000; Kita et al., 1995; Luo et al., 2005; Utelli et al., 2000; L. Wang et al., 2009).

Undiluted DNA extracts were used as templates in the amplification of both target sequences: $\operatorname{tr} n \mathrm{~L}^{(\mathrm{UAG})}-n d h \mathrm{~F}$ region: Primers

$t r n \mathrm{~L}^{(\mathrm{UAG})}-5^{\prime}$-CTGCTTCCTAAGAGCAGCGT- $3^{\prime}$ and $n d h \mathrm{~F}-5^{\prime}-$

GAAAGGTATKATCCAYGMATATT-3' (Shaw et al., 2007) and ITS region: Primers ITS7A - 5'-GGAAGGAGAAGTCGTAACAAGG-3' (Sang et al., 1995) and ITS4 - 5'-TCCTCCGCTTATTGATATGC-3' (White et al., 1990). The reaction mixture contained $1 \times$ DreamTaq Green buffer (ThermoFisher Scientific, USA), $3.5 \mathrm{mM} \mathrm{MgCl}_{2}, 0.08 \mathrm{mM}$ of each dNTP, $0.08 \mu \mathrm{M}$ of both primers, and 

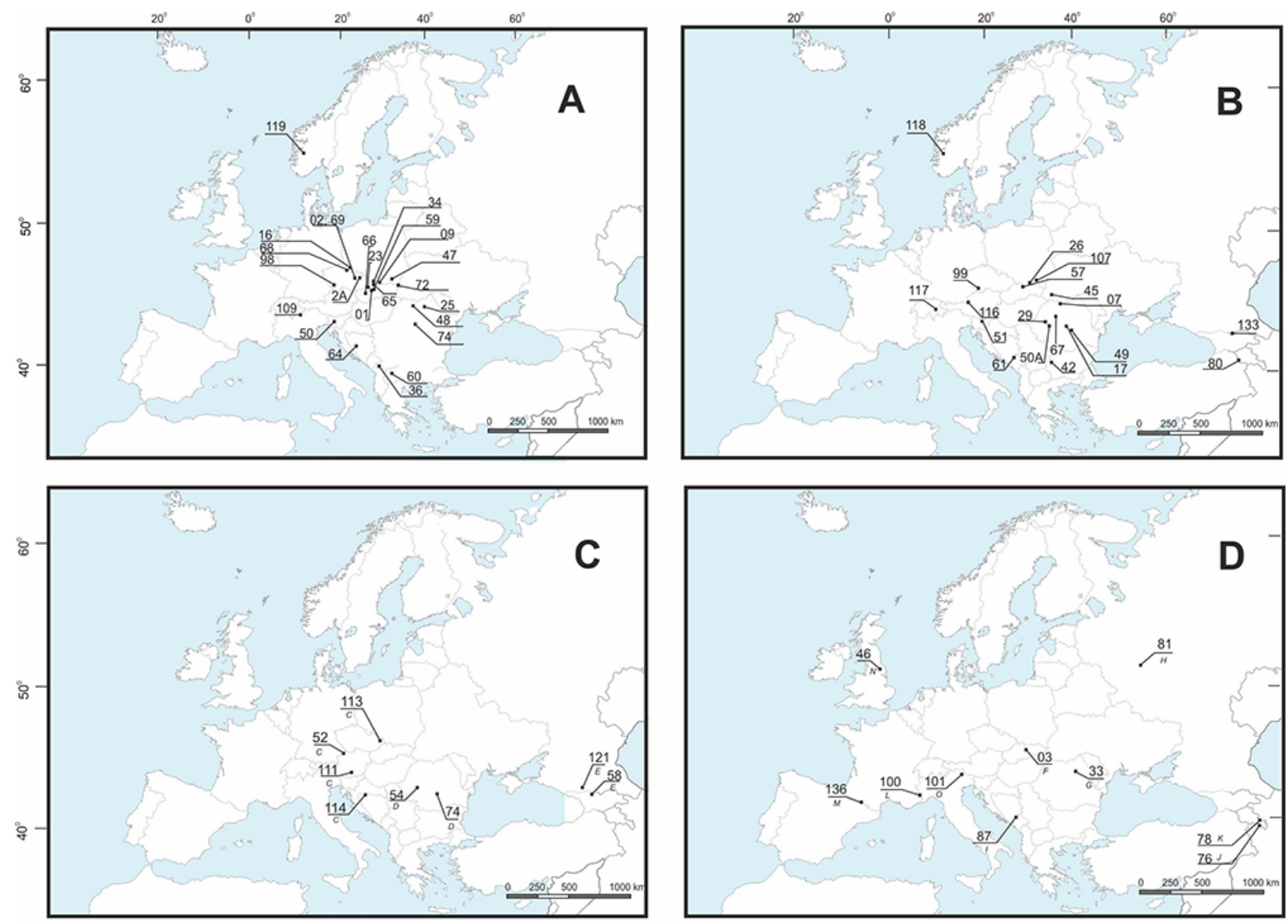

Figure 1 Geographical distribution of the cpDNA haplotypes of Aconitum subgen. Aconitum in Europe and the Caucasus. Haplotype A: Aconitum $\times$ cammarum 01; A. plicatum ssp. sudeticum 02, 2A, 68, 69; A. maninense 09, 23, 66; A. p. ssp. plicatum 16, 98 ; A. bucovinense 25, 72; A. nanum 32; A. firmum ssp. moravicum 34; A. pentheri 36, 60; A. f. ssp. firmum 47; A. czarnohorense 48; $A$. degenii ssp. paniculatum 50; A. lasiocarpum ssp. kotulae 59; A. superbum 64; A. ×berdaui 65; A. tauricum 109; A. f. ssp. firmum 119 (A). Haplotype $B$ : $A$. d. ssp. degenii 07; A. toxicum 17, 49, 61; A. variegatum ssp. variegatum 26; A. bucovinense 29; $A$. vitosanum $42 ; A$. d. ssp. intermedium 45; A. v. ssp. nasutum 51, 67, 99; A. ×pawlowskii 57, 107; A. toxicum 61; A. nasutum 80, 133; A. pilipes 116; A. d. ssp. rhaeticum 117; A. ×pawlowskii 118 (B). Haplotype C: A. hebegynum 52; A. d. ssp. paniculatum 111; A. Xexaltatum 113; A. v. ssp. nasutum 114; haplotype D: A. f. ssp. fissurae 54, A. bucovinense 74; haplotype E: A. n. ssp. pubiceps 58; A. cymbulatum 121 (C). Ten unique haplotypes - F: A. v. ssp. variegatum 03; G: A. l. ssp. lasiocarpum 33; H: A. firmum 81; I: A. superbum 87; J: A. nasutum 76; K: A. nasutum 78; L: A. burnatii 100; M: A. nevadense 136; N: A. anglicum 46; O: A. napellus 101 (D). For details on accessions origin see Table S1.

$1 \mu \mathrm{L}$ of DreamTaq DNA polymerase (ThermoFisher Scientific). Amplification was performed in a total reaction volume of $50 \mu \mathrm{L}$, using a T100 Thermal Cycler (Bio-Rad, USA) with the following temperature profiles:

- For the ITS fragment: $5 \mathrm{~min}$ at $94^{\circ} \mathrm{C} ; 25$ touchdown cycles of $30 \mathrm{~s}$ at $94{ }^{\circ} \mathrm{C} ; 30$ $\mathrm{s}$ at decreasing annealing temperature (from $62.5^{\circ} \mathrm{C}$ in the first to $48{ }^{\circ} \mathrm{C}$ in the thirtieth cycle); $1 \mathrm{~min}$ at $72{ }^{\circ} \mathrm{C}$; and 20 cycles of $30 \mathrm{~s}$ at $94{ }^{\circ} \mathrm{C}, 30 \mathrm{~s}$ at $55^{\circ} \mathrm{C}$, and 1 $\min$ at $72{ }^{\circ} \mathrm{C}$; followed by $10 \mathrm{~min}$ at $72{ }^{\circ} \mathrm{C}$.

- For the $\operatorname{trn} \mathrm{L}^{(\mathrm{UAG})}-n d h \mathrm{~F}$ fragment: $5 \mathrm{~min}$ at $94^{\circ} \mathrm{C} ; 25$ touchdown cycles of $30 \mathrm{~s}$ at $94{ }^{\circ} \mathrm{C}$; $30 \mathrm{~s}$ at decreasing annealing temperature (from $67.5^{\circ} \mathrm{C}$ in the first to 55 ${ }^{\circ} \mathrm{C}$ in the twenty-fifth cycle); $1 \mathrm{~min}$ at $72{ }^{\circ} \mathrm{C}$; and 20 cycles of $30 \mathrm{~s}$ at $94{ }^{\circ} \mathrm{C}, 30 \mathrm{~s}$ at $55^{\circ} \mathrm{C}$, and $1 \mathrm{~min}$ at $72{ }^{\circ} \mathrm{C}$; followed by $10 \mathrm{~min}$ at $72^{\circ} \mathrm{C}$.

Successful amplification was confirmed by agarose gel electrophoresis, and positive PCR products were purified using Clean-Up DNA purification kit (A\&A Biotechnology). The purified PCR products were used as templates in the sequencing reactions.

The two target regions were sequenced in both directions using the PCR primers. However, due to the greater length and frequent polynucleotide regions, a set of internal sequencing primers was used along with PCR 
primers to ensure bidirectional sequencing of the entire of $\operatorname{trn} \mathrm{L}^{(\mathrm{UAG})}$ ndhF spacer: V1_F - 5'-AGGTTGAGTTATTGGTGGATGA-3', V2_F - 5'-GTTCGCAAAGAACTGAAGTGAC-3', V3_F - 5' TGGATGATAGAATAYATATCAAAATCA-3' (forward primers), and V2_R - 5' -TTTCCGGATTCACCAGCTCTT-3' and V3_R - 5' CGAAAAGCCATTACATTCTTAAA-3' (reverse primers).

Sequencing was performed using BigDye Terminator v.3.1 Cycle Sequencing Kit (Life Technologies, USA) in a T100 thermal cycler (Bio-Rad) and 3500 Series Genetic Analyzer (Life Technologies), using standard protocols.

\subsection{Sequence Alignment}

Individual sequencing reads were examined carefully and compiled into full contigs with ChromasPro 1.7.6 software (Technelysium, Australia). As a relatively high level of nucleotide ambiguity was detected in the ITS sequences, the two independent reads for each contig had to be compared. A given nucleotide position was deemed ambiguous when two peaks were detected at the same position in the sequencing chromatogram, and the weaker peak was at least one third as high as the stronger peak in both independent reads (Fuertes-Aguilar \& Nieto-Feliner, 2003). Sequences with ambiguous positions, encoded according to the IUPAC nucleotide code, were used for all downstream analyses. Both ITS and $t r n \mathrm{~L}^{(\mathrm{UAG})}-n d h \mathrm{~F}$ contigs were aligned using the Clustal W algorithm (Thompson et al., 1994) of the MEGA 6 software package (K. Tamura et al., 2013), followed by manual adjustment.

\subsection{Phylogenetic Analyses}

Separate analyses of the $\operatorname{trn} \mathrm{L}^{(\mathrm{UAG})}-n d h \mathrm{~F}$ and ITS data sets produced no significant topological discordance for incongruent nodes with Bayesian inference (BI) and maximum likelihood (ML) bootstrap proportions $>70 \%$, and the datasets were therefore concatenated, yielding a matrix of 1,531 characters and 16 accession combinations (haplogroups), plus two accessions of the outgroup (Table 2). Substitution model parameters were estimated separately for each partition, using the GTR+G model (with four rate categories) for both the $\operatorname{tr} n \mathrm{~L}^{(\mathrm{UAG})}-n d h \mathrm{~F}$ and ITS regions. The model was selected by FindModel (https://www.hiv.lanl.gov/content/sequence/findmodel/findmodel.html), which uses the ModelTest script (Posada \& Crandall, 1998).

Tree searches were based on a BI method (Rannala \& Young, 1996) implemented in MrBayes v.1.10.4 (Huelsenbeck \& Ronquist, 2001; Ronquist et al., 2005). The analysis was carried out by sampling every hundredth generation for 5 million generations, starting with a random tree. The first 1,250 million generations were excluded as burn-in after convergence of the chains, which was evaluated by the average standard deviation of the splitting frequencies below 0.01 .

The ML analysis was performed for the concatenated data set in PhyML 3.0 (Guindon et al., 2010). The GTR model of nucleotide substitution was used. Parametric bootstrap values for ML were based on 400 replicates.

DNA sequences were also analyzed using the maximum parsimony (MP) optimality criterion (Felsenstein, 2004; Fitch, 1971) in PAUP* version 4.0.b10 (Swofford, 2002). A heuristic search was conducted with random addition, tree bisection-reconnection (TBR) branch swapping, and the MULTREES option on. The consistency index (CI) and retention index (RI) were calculated with PAUP*, excluding uninformative characters. The strict consensus tree and support for its branches were evaluated by bootstrapping (BS) (Felsenstein, 2004), with 174 bootstrap replicates, each with 10 random stepwise additions performed using the same settings as above, and no more than 100 trees were retained per replicate.

\subsection{Molecular Clock Analyses}

We used TempEst v.1.5.1 to test the clock-like behavior of the concatenated dataset (Rambaut et al., 2016). Divergence dating was performed in Beast v.1.10.4 (Drummond et al., 2006; Drummond \& Rambaut, 2007), which employs a Bayesian 
Table 2 Sixteen haplogroups (based on cpDNA haplotypes and ITS ribotypes) of Aconitum subgen. Aconitum in Europe and the Caucasus (including the 10 unique haplotypes) used in the phylogenetic analyses and the accessions within each haplogroup (species codes are given in Figure 1 and Table S1).

\begin{tabular}{|c|c|c|c|}
\hline Haplogroup/code & $\begin{array}{l}\text { cpDNA } \\
\text { haplotype }\end{array}$ & $\begin{array}{l}\text { ITS } \\
\text { ribotype }\end{array}$ & $\begin{array}{l}\text { No. of } \\
\text { accessions }\end{array}$ \\
\hline$A 1^{*}$ & $A$ & $\mathrm{R} 1$ & 20 \\
\hline A3 (64) & $A$ & R3 & 1 \\
\hline$A 4(60)$ & $A$ & $\mathrm{R} 4$ & 1 \\
\hline$B 1^{\star}$ (Europe + Caucasus $)$ & $B$ & $\mathrm{R} 1$ & 18 \\
\hline B5 (99) & $B$ & R5 & 1 \\
\hline$C 1^{*}$ & C & $\mathrm{R} 1$ & 4 \\
\hline$D 1^{*}$ & $D$ & $\mathrm{R} 1$ & 2 \\
\hline$E 2^{*}$ (Caucasus) & $E$ & $\mathrm{R} 2$ & 2 \\
\hline$F 1(03)$ & $F$ & $\mathrm{R} 1$ & 1 \\
\hline G1 (33) & $G$ & $\mathrm{R} 1$ & 1 \\
\hline$H 1(81)$ & $H$ & $\mathrm{R} 1$ & 1 \\
\hline II (87) & $I$ & $\mathrm{R} 1$ & 1 \\
\hline J6 (76) (Caucasus) & $J$ & R6 & 1 \\
\hline K7 (78) (Caucasus) & K & R7 & 1 \\
\hline L8 (100) & $L$ & $\mathrm{R} 8$ & 1 \\
\hline M9 (136) & $M$ & R9 & 1 \\
\hline \multicolumn{4}{|c|}{ Accessions not used in phylogenetic analyses } \\
\hline 02,50 & $A$ & n.d. & 2 \\
\hline 46 & $N$ & n.d. & 1 \\
\hline 101 & $O$ & n.d. & 1 \\
\hline $73,79,108$ & n.d. & $\mathrm{R} 1$ & 3 \\
\hline Total & - & - & 64 \\
\hline
\end{tabular}

${ }^{*}$ Codes: haplogroup $A 1: 01,09,16,23,25,32,34,36,47,48,59,65,66,68,69,72,98,109,119,02 \mathrm{~A}$ haplg. $B 1: 07,17,26,29,42,45,49,51,57,61,67,99,80,107,116,117,118,133,50 \mathrm{~A}$; haplg. $C 1: 52,111$, 113, 114; haplg. D1: 54, 74; haplg. E2: 58, 121. n.d. - not determined.

Markov chain Monte Carlo (MCMC) approach to coestimate topology, substitution rates, and node ages. All dating runs relied on the GTR+G model, a Yule prior, with uncorrelated and log-normally distributed rate variation across branches.

Several estimations of the divergence time between the subgenera Aconitum (ingroup) and Lycoctonum (outgroup) are available, considering the lack of any reliable Neogene Aconitum fossils. All these estimates were based on the generally accepted substitution rates, and served as secondary calibration points in Beast MCMC analyses, verified by cross-validated calibration approaches (Jabbour \& Renner, 2011a). Jabbour and Renner (2011b) estimated the split between A. subgen. Aconitum and A. subgen. Lycoctonum at ca. 11.49, Park et al. (2020) at 11.9, and Xiang et al. (2017) at 15.13 Mya. We considered the age at the divergence of the subgenera as 11.9 Mya (Park et al., 2020) for our analyses.

The MCMC algorithm was run for 3 million generations (25\% burn-in), with sampling at every thousandth generation and normal prior distributions and standard deviations of 3 Mya. Tracer v.1.7.1 (Rambaut et al., 2014) was used to confirm acceptable mixing, likelihood stationarity of the MCMC chain, and adequate effective sample sizes for each parameter $(>200)$. The minimum clade credibility tree and associated $95 \%$ highest posterior density distributions around the estimated node ages were computed using TreeAnnotator v.1.7.5. The constructed trees were visualized with FigTree v.1.4.3 (2016).

\subsection{Phylogenetic Networks}

To visualize genealogical relations among the cpDNA haplotypes, we used the TCS algorithm of Clement et al. (2000), implemented in POPART software (Leigh 
\& Bryant, 2105). It is based on the concept of statistical parsimony and aims at producing an unrooted haplotype phylogenetic network, in which two haplotypes are joined by an edge only if the "probability parsimony" exceeds 0.95 for that edge (Huson et al., 2010).

\section{Results}

\subsection{Characterization of Nucleotide Data}

The aligned ITS matrix included 18 unique sequences (16 ingroup + two outgroup) and a total of 632 positions, of which 557 were constant, 60 (9\%) were parsimonyinformative, and 15 were parsimony-uninformative.

For the cpDNA trnL-ndhF region, the matrix of 18 unique sequences contained a total of 899 positions, with 836 constant, 43 (5\%) potentially parsimony-informative, and 20 parsimony-uninformative positions.

The combined (cpDNA + ITS) matrix consisted of 18 unique sequences and 1,531 positions, including 1,408 constant, 35 (2\%) potentially parsimony-informative, and 88 parsimony-uninformative positions. Further information on the datasets and tree statistics from MP analyses of the nuclear and chloroplast regions and concatenated data is summarized in Table 3.

Table 3 Dataset and tree statistics from separate and combined analyses of nuclear (ITS) and chloroplast (cpDNA) regions, including the two outgroup accessions.

\begin{tabular}{llll}
\hline & ITS & $\begin{array}{l}\text { cpDNA } \\
\text { trn-ndhF }\end{array}$ & $\begin{array}{l}\text { Combined ITS + } \\
\text { cpDNA }\end{array}$ \\
\hline Sequences $(n)$ & 18 & 18 & 18 \\
CI of MPTs & 0.8989 & 0.9412 & 0.8889 \\
RI of MPTs & 0.9167 & 0.9434 & 0.9006 \\
Number of MPTs & 224 & 9 & 280 \\
Length of MPTs & 91 & 51 & 144 \\
\hline
\end{tabular}

CI - consistency index; MPT - most parsimonial tree; RI - retention index.

\subsection{Chloroplast DNA Variation and Geographic Distribution}

The 64 accessions of Aconitum subgen. Aconitum (excluding the outgroup accessions) could be categorized into five cpDNA haplotypes, i.e., haplotype $A$ (24 specimens), $B$ (19), $C$ (four), $D$ (two), and $E$ (two), whereas the remaining 10 sequences were unique (Figure $1 \mathrm{~A}-\mathrm{D}$, Table 2). The $\operatorname{trn} \mathrm{L}^{(\mathrm{UAG})}-n d h \mathrm{~F}$ region could not be amplified in three accessions, namely accessions 73, 79, and 108 (Table 2). Haplotype $A$ was distributed across Europe, hapl. $B$ in Europe and the Caucasus, hapl. $C$ was absent in the Carpathians but present in the Alps, Sudetes, and West Balkans, and hapl. $D$ and hapl. E occurred exclusively in the South Carpathians or the Caucasus, respectively (Figure 1).

Table 4 and Table 5 summarizes the site variations within the cpDNA haplotypes. The most conspicuous genetic feature were the unique indels (sites 540-544 and 602-603) that distinguished the diploids from the tetraploids. In this context, the Caucasian accessions appeared to correspond to the tetraploids. They shared indels 602-603 and 648-654 with the tetraploid group, excluding the A. burnatii/nevadense group. A. burnatii and $A$. nevadense could be distinguished by a substitution at site 505, and from the diploids and tetraploids by indels 540-544 and 648-654, respectively (Table 4). The Caucasian group was heterogeneous. Haplotype $K$ could be identified by indels $612-616$ and $723-731$, hapl. $J$ by indels $807-821$, and hapl. $E$ by sites 781 and 602-603. In comparison, the diploid group was relatively uniform, and point mutations were noted at sites 36, 91, and 118 and indels at sites 328, 333340, and 807-821 (Table 4 , Table 5). 


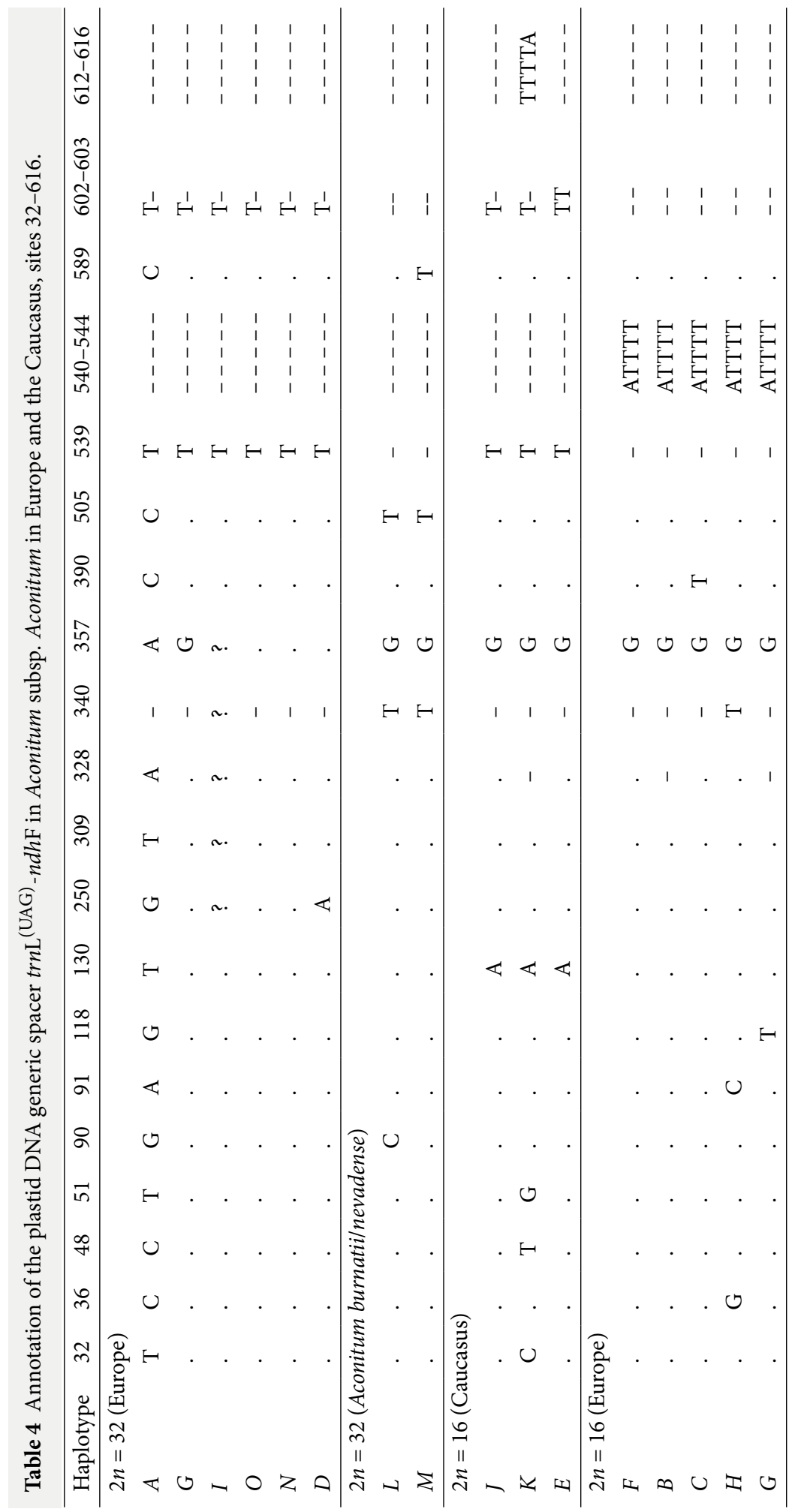




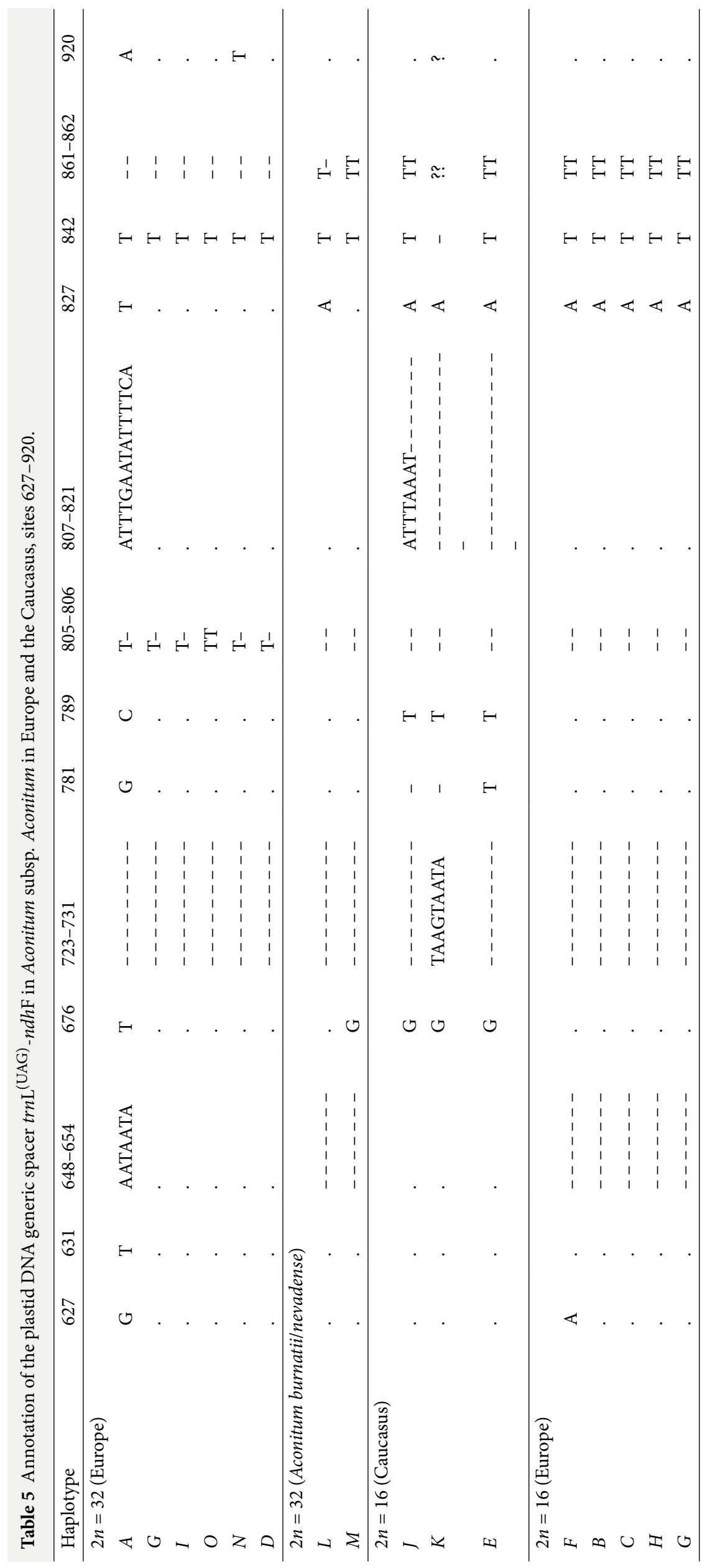




\subsection{Nuclear ITS Genotype Variation}

We observed extremely low nucleotide variation in Aconitum ITS sequences. The 64 accessions (excluding two of the outgroup) were arranged in two ITS ribotypes: R1 (51 specimens) and R2 (two specimens); the remaining seven sequences represented specific ribotypes (ribotypes R3-R9; Table 2). The ITS region of four accessions, namely $02,46,50$, and 101, could not be amplified. R1 was distributed across Europe and Caucasus, and R2, R6, and R7 occurred only in the Caucasian Mts (Table 2).

\subsection{Phylogenetic Analysis}

The BI tree, based on the combined DNA plastid and ITS dataset arranged into 16 haplogroups (Table 2), is presented in Figure 2. It suggested the basal, statistically supported position of the Caucasian species (haplogroup E), A. nasutum 76 (haplg. J6), and A. nasutum 78 (haplg. K7) to the European clade. Among the core European clades, two species from the Maritime Alps/Pyrenees, namely $A$. burnatii 100 (haplg. L8) and A. nevadense 136 (haplg. M9), formed a sister group to the remaining species, with high BI (1.00) and ML bootstrap support (94\%) values. The core of the European species was divided into two clades, i.e., the diploid (0.80 BI, 90\% ML, 77\% MP) and tetraploid species (0.99 BI, 79\% ML, 91\% MP). Two tetraploids [A. firmum 81 (haplg. H1) and A. superbum 87 (haplg. I1)] were included in the diploid clade. This clade also included haplogroup $B 1$, consisting of both European and Armenian/Caucasian species (Figure 1B). A sister group with moderate support $(0.88 \mathrm{BI}, 0.90 \%, \mathrm{ML}, 63 \% \mathrm{MP})$, constituted of two species, namely A. variegatum 03 (haplg. F1) and A. nasutum 99 (haplg. B5), was also included in this clade (Figure 1).

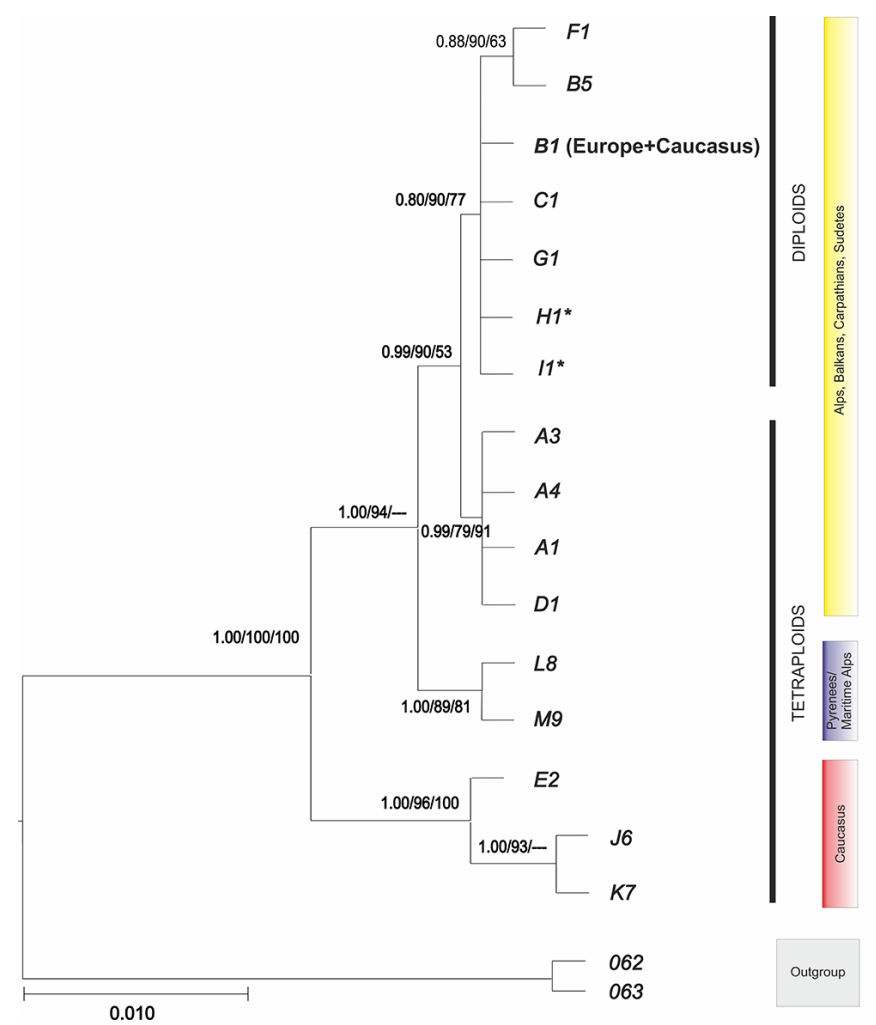

Figure 2 Bayesian inference tree of Aconitum subgen. Aconitum in Europe and the Caucasus based on concatenated cpDNA + ITS data (haplogroups). The numbers above branches indicate a posteriori probability (BI) and percentage bootstrap values for maximum likelihood (400 replications) and minimum parsimony (174 replications), respectively; ${ }^{*}$ - tetraploids. A1 (20 taxa), A3 - A. firmum ssp. fissurae (the Carpathians), A4 - A. pentheri, B1 (18 taxa), B5 - A. variegatum ssp. nasutum (Šumava, Czech R.), C1 (four taxa), D1 (two taxa), E2 (two taxa), F1 - A. v. ssp. variegatum, G1 - A. lasiocarpum, H1 - A. f. ssp. firmum (Russian Upland), I1 - A. superbum, J6 - A. nasutum (Azerbaijan), K7 - A. nasutum (Armenia), L8 - A. burnatii, M9 - A. nevadense, 62 - A. moldavicum, 63 - A. lycoctonum (for haplogroups B1, C1, D1, and E2, see Table 2 and Figure 1). 


\subsection{Haplotype Network}

The TCS haplotype network of cpDNA haplotypes (Figure 3) showed a split between the diploid hapl. $B$ and tetraploid hapl. $A$. Among ingroup haplotypes, those from the Pyrenees/Maritime Alps were genetically the most remote and characterized by intermediate hypothetical haplotypes. These haplotypes, together with hapl. $A$ and $B$, formed a cyclic node-set, suggesting reticulation. Hapl. $B$ exhibited a starlike pattern, with the other diploid haplotypes radiating out, and linked with the Caucasian species.

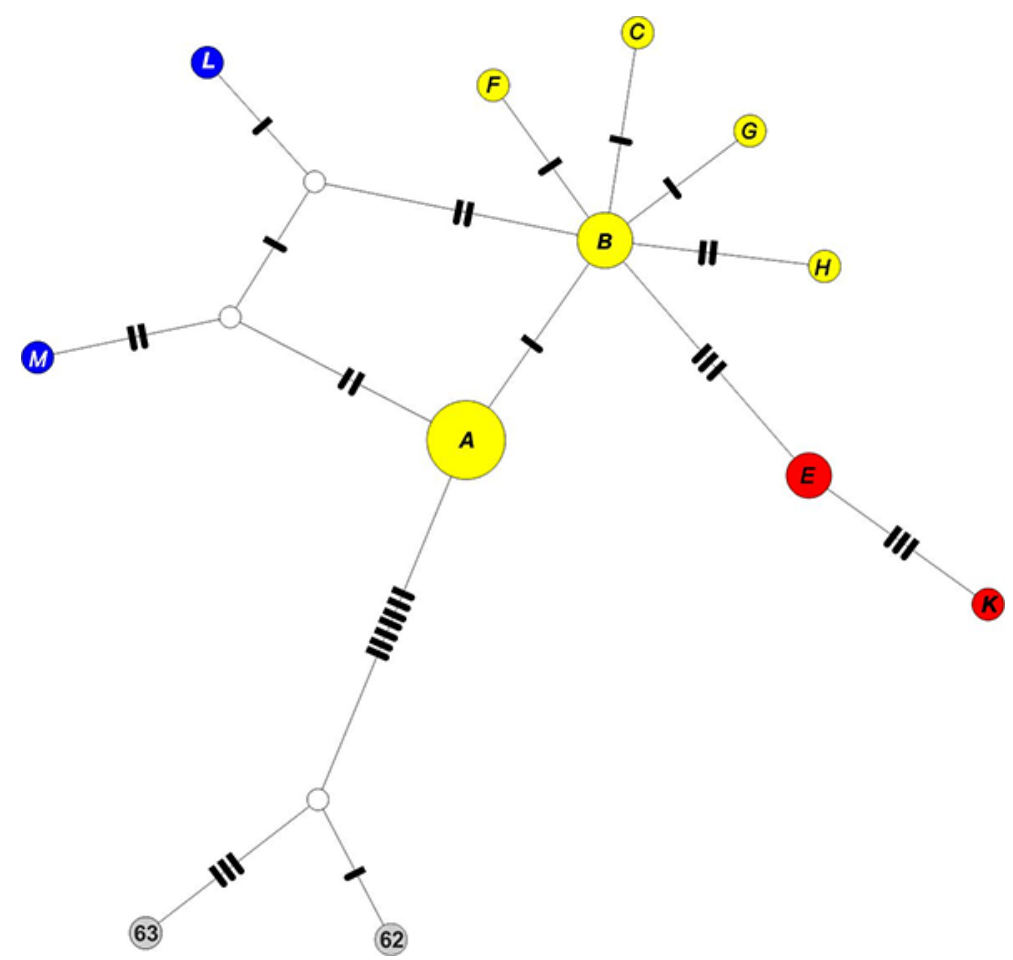

Figure 3 Haplotype cpDNA $(A-K)+$ outgroup network obtained from the TCS analysis. The size of the circles is proportional to the frequency of each haplotype. Each bar represents a single mutational change and open circles represent hypothetical haplotypes not observed in this study. Circle colors: blue - Sierra Nevada/the Maritime Alps, yellow - rest of Europe, red - the Caucasus, grey - outgroup. For geographical distribution of haplotypes see Figure 1.

\subsection{Molecular Clock Estimations}

Divergence time estimates for Aconitum in Europe and the Caucasus Mts are shown in Figure 4. The Bayesian analysis showed that the earliest split of the Caucasian genetic stock occurred around 7.3 Mya (Late Miocene). The earliest divergence in Europe was between Aconitum burnatii and A. nevadense, at the Miocene/Pliocene break approximately 4.4 Mya, and the remaining European diploids and tetraploids started to differentiate ca. 2.6 Mya. Diversification within the diploid and tetraploid sections appeared at the beginning of the Quaternary 1.8 Mya and continued till 0.5 Mya (Figure 4).

\section{Discussion}

\subsection{Geographic-Historical Background}

The occurrence of Aconitum in Central Europe can be traced back to as early as the Late Miocene, as suggested by the Aconitum pollen deposits found in the Central Paratethys realm (Central Europe) (Stuchlik \& Shatilova, 1987). The Caucasian and European lines diverged in the Late Miocene, and internally diversified mainly in 

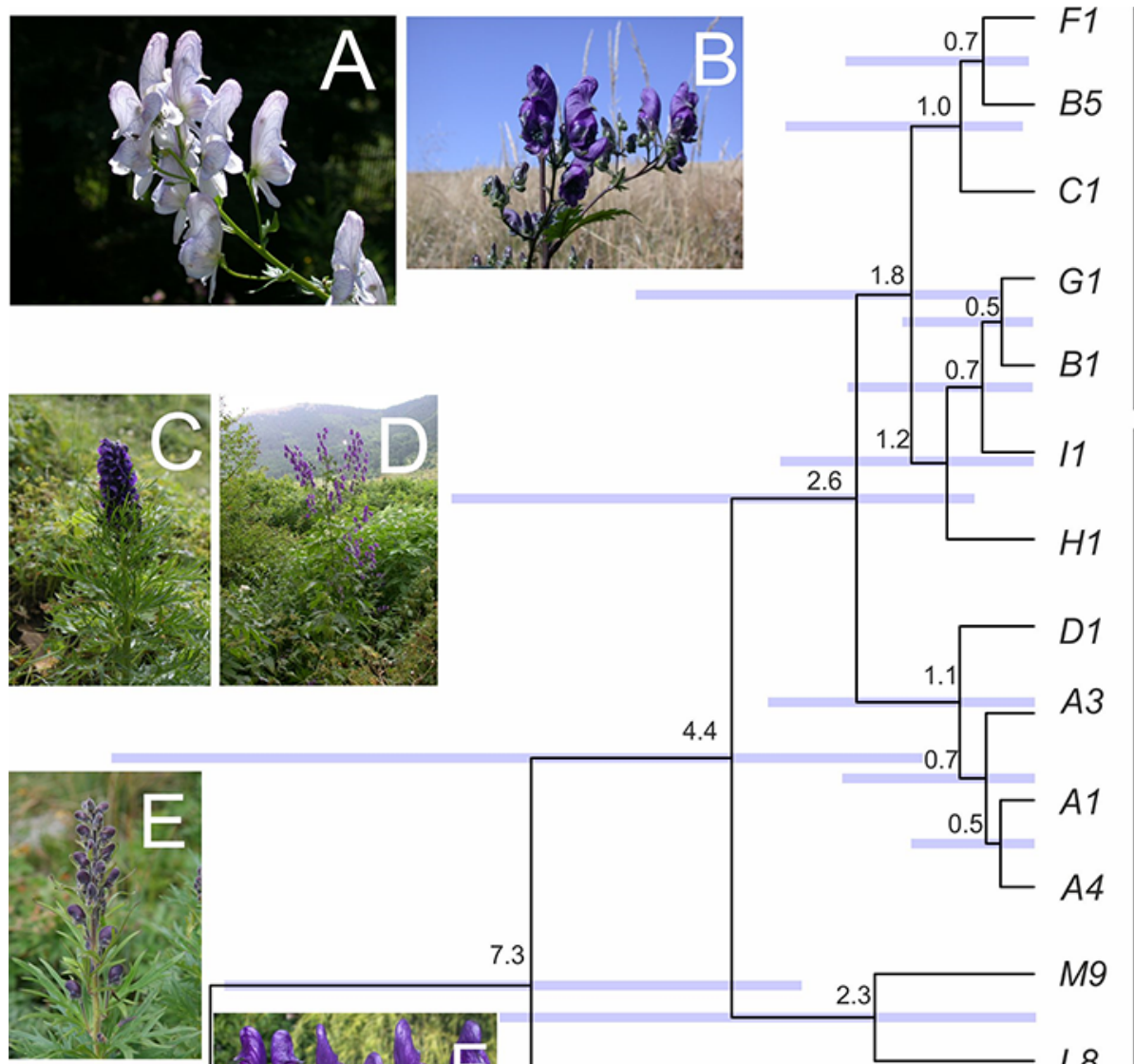

L8

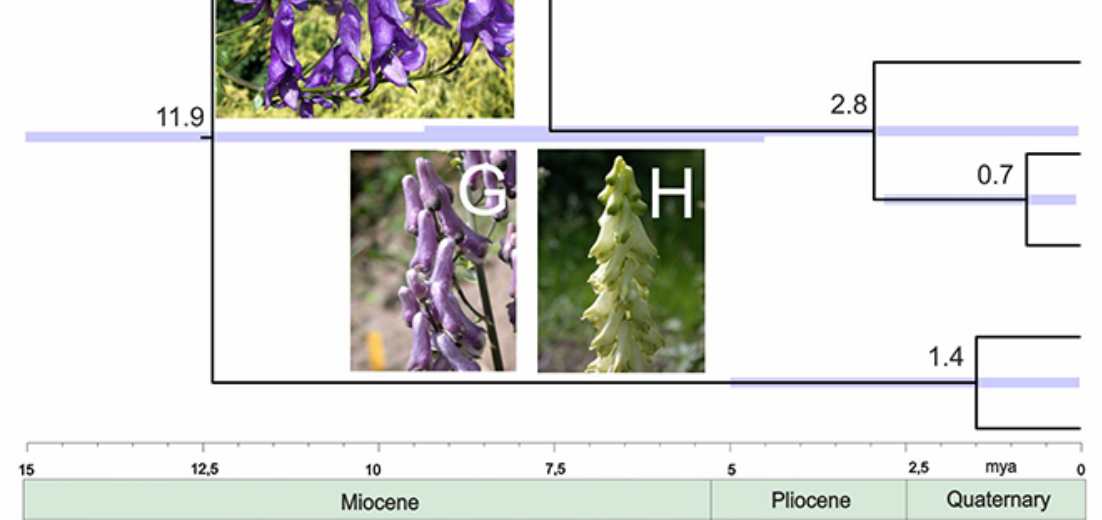

Outgroup

Figure 4 Molecular clock chronogram of Aconitum subgen. Aconitum in Europe and the Caucasus Mts based on cpDNA + ITS concatenated sequence data (haplogroups) created using BEAST. Bars indicate the $95 \%$ posterior density distribution of the nodes and the horizontal axis shows the divergence time of the lineages in million years. The calibration point was 11.9 Mya, according to Park et al. (2020). Photos (๔ J. Mitka): A. variegatum, Muranska planina, Slovakia (A); A. lasiocarpum, West Bieszczady Mts, East Carpathians, Poland (B); A. napellus, Alps, Dolomites, Italy (C); A. superbum, Dinaric Mts, Bosnia and Hercegovina (D); A. burnatii, Alpes Maritimes, Italy (E); A. nasutum, Transsilvania, Romania (F); A. moldavicum, West Bieszczady Mts, Poland (G); A. lycoctonum, Beskids Mały, West Carpathians, Poland (H). For haplogroups, see Table 2 and Table S1.

the Quaternary, similarly to Ranunculus s. s. (Paun et al., 2005), Syringa (Kim \& Jensen, 1998), and Wulfenia (Surina et al., 2014), highlighting the significance of this period for the evolution of the European mountain and high-mountain flora.

During the Late Miocene, the temperate forests along the southern coasts of Central and Eastern Parathetys (spread to Western Asia) were continuously replaced by open woodlands. The aridization trend corresponded to forest fragmentation and appearance of open landscapes, the development of grasslands and xerophytic plant communities, and disappearance of subtropical species from the fossil flora (see Dénes et al., 2015; Ivanov et al., 2011). The process was accompanied by a remarkable shift in the composition of fossil mammal assemblages from the 
Early/Middle Pannonian to the Late Pannonian, reflecting an increase in the seasonality and aridity in the Pannonian Basin area (Harzhauser et al., 2004). The ongoing fragmentation of forests could have disrupted the continuous Aconitum distribution along the southern coast of the Parathetys, contributing to its geographic isolation and evolutionary divergence. This process is illustrated by the Aconitum haplogroup B1 and A. nasutum in the Caucasus and Europe.

\subsection{The Role of the Caucasus and Central Asia in the European Alpine System}

The Caucasus represents a spatial and evolutionary link for many European genera of Asian origin (Ozenda, 2009), for example the genera Trollius L. (Després et al., 2003), Acer L. (Grimm \& Denk, 2014), and Prunus (Volkova et al., 2020). The Asian genetic stock underwent further evolutionary migration to Europe (via the Caucasus and Balkans), i.e., phylogenetic divergence leading to the origin of sister taxa (Bräuchler et al., 2004; Dumolin-Lapègue et al., 1997; Song et al., 2016). The relationships between these regions appear to be older than the Quaternary (Hantemirova et al., 2016). This scenario may have applied to only the diploid line of Aconitum, and the current links between Europe and the Caucasus have been preserved in the diploid cpDNA of haplotype $B$. In a study on Aconitum in Bela Krajina (Slovenia), Starmühler (1996) discovered a Caucasian species, $A . \times$ tuscheticum (N. Busch) N. Busch (see Luferov, 2000), another putative relict of the South European-Caucasian floristic links.

The historical relationships between the Transcaucasia [including Hyrcan and Colchis Tertiary refuges; see Maharramova et al. (2015)] and Europe are well known (Mai, 1995). The European Alpine system, the Caucasus, mountains of Central Asia, and stations on the Russian Lowland constitute the Altaic-Alpic geographical subelement, represented by the geographical range of Juniperus sabina L. (Zając \& Zając, 2009), Saxifraga androsacea L., and Avenula versicolor (Vill.) M. Lainz (Pawłowski, 1929). The phylogeographic links between Central Asia and the European Alpine system, especially in Southeastern Europe, are unexpectedly well pronounced in some cases (Kadereit et al., 2008; Ronikier, 2011; Winkler et al., 2012).

\subsection{Independent Evolution of Diploid and Tetraploid Lines}

The origin and monophyly of the core European Aconitum subgen. Aconitum remains elusive. Molecular clock analysis dated the split of the tetraploids from the diploid stock at the beginning of the Quaternary (ca. 2.6 Mya). The sister position of the diploid and tetraploid lineages could be misleading, as they could not have originated in situ from a common ancestor and might represent independent genetic lineages in Europe. In this context, A. subgen. Aconitum in Europe could be a nonmonophyletic group.

The simplest "monophyletic" scenario is that the group originated in situ from an ancient, local diploid stock. Molecular analyses did not retrieve any extant diploid species as basal to the tetraploid group in Europe, as was observed for the Japanese tetraploids, where a diploid species, $A$. volubile Koelle, formed a monophyletic group with all East Asian tetraploid taxa, strongly suggesting it as their ancestral species (Kita \& Ito, 2000).

However, some extant European tetraploids could have originated in situ from the local, possibly extinct, diploid genetic stock (Mitka et al., 2007), e.g., A. firmum and $A$. superbum, presently placed in the diploid clade. Their current position among the diploids is probably a relic of their initial diploid state and subsequent tetraploidization or horizontal gene transfer via intersectional hybridization (see below). Whole-genome duplication followed by diploidization in the ancient lineages support the hypothesis of Aconitum palaeoploidy (Park et al., 2020).

Excessive accumulation of 5S rDNA clusters in Aconitum chromosomes (FISH) in the tetraploid species (A. firmum and A. plicatum), followed by a reduction of the basal genome size (Joachimiak et al., 2018), likely occurred during diploidization, which is one of the stages of the cyclical process described as the "wondrous cycle of polyploidy" in plants. It could be a nonrandom process, as suggested by the 
retention of the original diploid ancestral progenitor genomes (Wendel, 2015), at least partially responsible for the paraphyly of the tetraploid and polyphyly of the diploid clades.

Weak support of the European diploid clade and links with the Caucasian genetic stock (haplogroup B1) might indicate its origin from multiple ancestor species that disappeared between 4.4-2.6 Mya. If this is the case, their roots could trace back to arctiotertiary temperate forest elements of Asian origin (Baskin \& Baskin, 2016; Deng et al., 2015; Popov, 1983; Zhang et al., 2014). Some of them disappeared completely, whereas some underwent evolutionary divergence, including genome doubling (tetraploidization), when the global temperatures dropped markedly towards the end of the Pliocene (Abbott, 2008; Hultén, 1937).

\subsection{Palaeonedemic Status of Aconitum burnatii/nevadense}

Aconitum burnatii and A. nevadense represent the oldest genetic line in Europe, dating back to ca. 4.4 Mya. Their present position at the base of the entire European genetic stock could be a result of their initial diploid status and further palaeoploidisation or speciation by ploidy (see Brochmann et al., 1998; Favarger, 1960; Verlaque et al., 1997). According to this hypothesis, both A. burnatii and $A$. nevadense are autotetraploids, arising from conspecific Tertiary diploid parents, which are now extinct. It may have occurred at the time of the Neogene cooling phases, which culminated in the onset of major glaciation in the Northern Hemisphere (Pearson \& Palmer, 2000). It is widely accepted that environmental stress resulting from the climatic cooling episodes was the driving force behind the widespread formation of polyploids. These species often occupy habitats different from those of their diploid parents and have been proposed as superior colonizers (Baduel et al., 2018; Soltis \& Soltis, 2000; Stebbins, 1984). This relict group exhibited an independent evolutionary trajectory from the European Aconitum since the Miocene/Pliocene break. Another hypothesis states that the oldest diploid genetic lineage in Europe originated from the extant Central/East Asian diploid species, and this warrants further investigation.

The Pyrenees, Sierra Nevada, and the Maritime Alps, where paleoendemic Aconitum species occur, are one of the most important "cumulative refugial" areas of Mediterranean flora (Aeschimann et al., 2011; Casazza et al., 2005; Médail \& Diadema, 2009) and fauna (Schmitt, 2009) in Europe, representing floristic (Pauli et al., 2003; Väre et al., 2003) and "phylogeographical" (Médail \& Diadema, 2009) hotspots. The refugial character of the Pyrenees was further confirmed by a phylogeographic study on the subalpine herb Ranunculus platanifolius (StachurskaSwakon et al., 2013), where the number of AFLP genetic groups was the highest across the European mountain ranges. The Maritime and Ligurian Alps are believed to be shelters for many Tertiary species, including Saxifraga florulenta Moretti, Silene cordifolia All., Berardia subacaulis Vill., and Viola argenteria B. Moraldo \& G. Forneris (see Casazza, Barberis, et al., 2016; Cassaza, Zappa, et al., 2016).

A mechanism underlying the origin of such a pattern could be explained using the example of Silene ciliata Pourret, whose ancestral populations in the Mediterranean Basin might have been forced to migrate northward at the onset of climatic oscillations during the Late Tertiary and the Quaternary periods, resulting in the gradual taxonomic and phylogenetic splitting of the once monophyletic group (Kyrkou et al., 2015).

\subsection{Reticulation Among European Aconitum}

We believe that intersectional hybridization and subsequent genetic introgression are the most relevant factors responsible for the paraphyly of the tetraploid clade (Figure 2) (Mitka et al., 2007, 2015; Sutkowska, Boroń, et al., 2017; Sutkowska, Warzecha, \& Mitka, 2017). Hybridization is frequent in Aconitum (Kita \& Ito, 2000). Present horizontal transfer of the cpDNA gene between diploid and tetraploid Aconitum species (via reverse "triploid bridge") has been reported in the Tatra Mts (Sutkowska, Boroń, et al., 2017, Zieliński, 1982a, 1982b). Such horizontal gene transfer could be responsible for the observed interchange of cpDNA between the different sections of $A$. subgen. Aconitum in Europe. 
The TCS algorithm showed ancient reticulation among the hypothetical ancestors of the A. burnatii/nevadense group and diploid/tetraploid haplotypes. All these observations indicate the ancient and complicated evolutionary history of the subgenus in Europe, including palaeoploidization, and recent and historical reticulations.

\subsection{Taxonomic Consequences}

The relationships between Caucasian and Balkan/Alpine A. nasutum Rchb. (Götz, 1967) remain to be resolved. This species includes both diploid and tetraploid lines (Mucher, 1991, Seitz et al., 1972). According to our results, the Caucasian accessions of $A$. nasutum $(76,78)$ are tetraploids. Moreover, according to Seitz et al. (1972), A. nasutum from Northeast Turkey is tetraploid. The TranscaucasianEuropean A. nasutum 051, 080, 099, and 133 (haplotype B) were diploids, based on the marker indel 540-544. Thus, they may belong to different sections, and their taxonomic status should be reevaluated based on their morphological, genetic, and cytogenetic data from Europe, Asia Minor, and the Caucasus. A Caucasian/Asian Minor tetraploid species A. nasutum Fisch. ex Rchb. Il. Acon. 9, 1 (1823) emend. Rupr. Fl. Cauc.: 39 (1869) belonging to sect. Aconitum subsect. Catenata (Steinb. ex H. Riedl) Luferov (2000) was described from the Caucasus [Type: "ad Caucasicum, Herb v. Chamisso!” (Reichenbach, 1819); Distribution: Armenia, Iran, Turkey (Davis, 1965; Luferov, 2000)].

\section{Conclusion}

The diploid and tetraploid lines of Aconitum in Europe form independent phylogenies. The links of the European and Caucasian diploid species represented by haplotype $B$ indicate its ancient history in the region and arctiotertiary Asian origins. Paraphyly in the tetraploid clade could have been caused by ancient and present horizontal gene transfer at the section level. High-mountain European tetraploids likely originated from unknown ancestors in the Miocene age, presumably of Asian origin, as early as ca. 2.6 Mya, which is the estimated divergence time for the diploid and tetraploid lines in Europe. Similarly, presumed ancestral diploids, presently extinct, could be ancestral to the extant tetraploid $A$. burnatii/nevadense line, independent at least since the Late Miocene/Pliocene (4.4 Mya), which may have undergone tetraploidization and evolutionary divergence at least ca. 2.3 Mya.

\section{Supporting Material}

The following supporting material is available for this article:

- Table S1. List of the Aconitum accessions from Europe and the Caucasus used in this study.

\section{Acknowledgments}

We would like to thank the curators at KRA, KRAM, LW, and LWS herbaria for providing the Aconitum accessions, and especially Dr. Nataliya Shiyan at KV. We thank Dr. Florjan Jabbour for his critical comments on an earlier version of the manuscript.

\section{References}

Abbott, R. J. (2008). History, evolution and future of arctic and alpine flora: Overview. Plant Ecology and Diversity, 1, 129-133. https://doi.org/10.1080/17550870802460976

Aeschimann, D., Rasolofo, N., \& Theurillat, J. P. (2011). Analyse de la flore des Alpes. 1: historique et biodiversité [Analysis of the flora of the Alps. 1: historical account and biodiversity]. Candollea, 66, 27-55. https://doi.org/10.15553/c2011v661a2

Anderson, C. L., Bremer, K., \& Friis, E. M. (2005). Dating phylogenetically basal eudicots using $r b c L$ sequences and multiple fossil reference points. American Journal of Botany, 92, 1737-1748. https://doi.org/10.3732/ajb.92.10.1737

Baduel, P., Bray, S., Vallejo-Marin, M., Koláŕ, L., \& Yant, L. (2018). The "polyploidy hop": Shifting challenges and opportunities over the evolutionary lifespan of genome duplications. Frontiers in Ecology and Evolution, 6, Article 117. https://doi.org/10.3389/fevo.2018.00117 
Baskin, J. M., \& Baskin, C. C. (2016). Origins and relationships of the mixed mesophytic forest of Oregon-Idaho, China, and Kentucky: Review and synthesis. Annals of the Missouri Botanical Garden, 101, 525-552. https://doi.org/10.3417/2014017

Bosch, M., Simon, J., López-Pujol, J., \& Blanché, C. (2016). A conspect of chromosome numbers in tribe Delphinieae (Ranunculaceae). Universitat de Barcelona Digital Repository. http://hdl.handle.net/2445/98702

Bräuchler, C., Meimberg, H., \& Heubl, G. (2004). Molecular phylogeny of the genera Digitalis L. and Isoplexis (Lindley) Loudon (Veronicaceae) based on ITS- and trnL-F sequences Plant Systematics and Evolution, 248, 111-128. https://doi.org/10.1007/s00606-0040145-z

Brochmann, C., Xiang, Q. Y., Brunsfeld, S. J., Soltis, D. E., \& Soltis, P. S. (1998). Molecular evidence for polyploid origins of Saxifraga (Saxifragaceae): The narrow arctic endemic S. svalbardensis and its widespread allies. American Journal of Botany, 85, 135-143. https://doi.org/10.2307/2446562

Casazza, G., Barberis, G., Guerrina, M., Zappa, E., Mariotti, M., \& Minuto, L. (2016). The plant endemism in the Maritime and Ligurian Alps. Biogeographia - The Journal of Integrative Biogeography, 31, 73-88. https://doi.org/10.21426/B631132738

Casazza, G., Barberis, G., \& Minuto, L. (2005). Ecological characteristics and rarity of endemic plants of the Italian Maritime Alps. Biological Conservation, 123, 361-371. https://doi.org/10.1016/j.biocon.2004.12.005

Casazza, G., Zappa, E., Mariotti, M., Médail, F., \& Minuto, L. (2016). Ecological and historical factors affecting distribution pattern and richness of endemic plant species: The case of the Maritime and Ligurian Alps hotspots. Diversity and Distributions, 14, 47-58. https://doi.org/10.1111/j.1472-4642.2007.00412.x

Clement, M., Posada, D., \& Crandall, K. (2000). TCS: A computer program to estimate gene genealogies. Molecular Ecology, 9, 1657-1659. https://doi.org/10.1046/j.1365294x.2000.01020.x

Davis, D. (1965). Flora of Turkey and the East Aegean Islands. University Press.

Dénes, A. L., Kolcsár, L. P., Török, E., \& Keresztes, L. (2015). Phylogeography of the micro-endemic Pedicia staryi (Insecta: Diptera): Evidence of relict biodiversity of the Carpathians. Biological Journal of the Linnean Society, 119, 719-731. https://doi.org/10.1111/bij.12667

Deng, T., Nie, Z. L., Drew, B. T., Volis, S., Kim, C., Xiang, C. L., Zhang, J. W., Wanh, Y. H., \& Sun, H. (2015). Does the Arcto-Tertiary biogeographic hypothesis explain the disjunct distribution of Northern Hemisphere herbaceous plants? The case of Meehania (Lamiaceae). PLoS One, 10(2), Article e0117171. https://doi.org/10.1371/journal.pone.0117171

Després, L., Gielly, L., Redoutet, B., \& Taberlet, P. (2003). Using AFLP to resolve phylogenetic relationships in a morphologically diversified plant species complex when nuclear and chloroplast sequences fail to reveal variability. Molecular Phylogenetics and Evolution, 27, 185-196. https://doi.org/10.1016/S1055-7903(02)00445-1

Drummond, A. J., Ho, S. Y. W., Phillips, M. J., \& Rambaut, A. (2006). Relaxed phylogenetics and dating with confidence. PLoS Biology, 4(5), Article e88. https://doi.org/10.1371/journal.pbio.0040088

Drummond, A. J., \& Rambaut, A. (2007). BEAST: Bayesian evolutionary analysis by sampling trees. BMC Evolutionary Biology, 7, Article 214. https://doi.org/10.1186/1471-2148-7214

Dumolin-Lapègue, S., Demesure, B., Fineschi, S., LeCorre, V., \& Petit, R. J. (1997). Phylogeographic structure of white oaks throughout the European continent. Genetics, 146, 1475-1487.

Favarger, M. (1960). Sur l'emploi des nombres de chromosomes en géographie botanique historique [On the use of chromosome numbers in history of biogeography]. Berichte des Geobotanischen Institutes der ETH, Stiftung Rübel, 32, 119-146.

Felsenstein, J. (2004). Inferring phylogenies. Sinauer Associates.

Fitch, W. M. (1971). Toward defining the course of evolution: Minimum change for a specified tree topology. Systematic Zoology, 20, 406-416. https://doi.org/10.1093/sysbio/20.4.406

Fuertes-Aguilar, J., \& Nieto-Feliner, G. (2003). Additive polymorphisms and reticulation in an ITS phylogeny of thrifts (Armeria, Plumbaginaceae). Molecular and Phylogenetic Evolution, 28(3), 430-447. https://doi.org/10.1016/S1055-7903(02)00301-9

Götz, E. (1967). Die Aconitum variegatum-Gruppe und ihre Bastarde in Europa [The Aconitum variegatum group and its hybrids in Europe]. Feddes Repertorium, 76(1-2), 1-62. https://doi.org/10.1002/fedr.19670760102

Grimm, G. W., \& Denk, T. (2014). The Colchic region as refuge for relict tree lineages: Cryptic speciation in field maples. Turkish Journal of Botany, 38, 1050-1066. https://doi.org/10.3906/bot-1403-87 
Guindon, S., Dufayard, J. F., Lefort, V., Anisimova, M., Hordijk, W., \& Gascuel, O. (2010). New algorithms and methods to estimate maximum-likelihood phylogenies: Assessing the performance of PhyML 3.0. Systematic Biology, 59, 307-321. https://doi.org/10.1093/sysbio/syq010

Hantemirova, E., Heinze, B., Knyazeva, S. G., Musaev, A. M., Lascoux, M., \& Semerikov, V. L. (2016). A new Eurasian phylogeographical paradigm? Limited contribution of southern populations to the recolonization of high latitude populations in Juniperus communis L. (Cupressaceae). Journal of Biogeography, 44, 271-282. https://doi.org/10.1111/jbi.12867

Harzhauser, M., Daxner-Höck, G., \& Piller, W. E. (2004). An integrated stratigraphy of the Pannonian (Late Miocene) in the Vienna Basin. Austrian Journal of Earth Sciences, 95-96, 6-19.

Hong, Y., Luo, Y., Gao, Q., Ren, C., Yuan, Q., \& Yang, Q. E. (2017). Phylogeny and reclassification of Aconitum subgenus Lycoctonum (Ranunculaceae). PLoS One, 12(1), Article e0171038. https://doi.org/10.1371/journal.pone.0171038

Hörandl, E. (2006). Paraphyletic versus monophyletic taxa - Evolutionary versus cladistic classifications. Taxon, 55, 564-570. https://doi.org/10.2307/25065631

Huelsenbeck, J. P., \& Ronquist, F. (2001). MrBayes: Bayesian inference of phylogenetic trees. Bioinformatics, 17, 754-755. https://doi.org/10.1093/bioinformatics/17.8.754

Hultén, E. (1937). Outline of the history of arctic and boreal biota during the Quaternary period. Bokförlags aktiebolaget.

Huson, D. H., Rupp, R., \& Scornavacca, C. (2010). Phylogenetic networks. Concepts, algorithms and applications. University Printing House. https://doi.org/10.1017/CBO9780511974076

Ilnicki, T., \& Mitka, J. (2009). Chromosome numbers in Aconitum sect. Aconitum (Ranunculaceae) from the Carpathians. Caryologia, 62, 198-203. https://doi.org/10.1080/00087114.2004.10589685

Ilnicki, T., \& Mitka, J. (2011). Chromosome numbers in Aconitum sect. Cammarum (Ranunculaceae) from the Carpathians. Caryologia, 64, 446-452. https://doi.org/10.1080/00087114.2011.10589812

Ivanov, D., Utescher, T., Mosbrugger, V., Syabryay, S., Djordević-Milutinović, D., \& Molchanoff, S. (2011). Miocene vegetation and climate dynamics in Eastern and Central Paratethys (Southeastern Europe). Palaeogeography, Palaeoclimatology, Palaeoecology, 304, 262-275. https://doi.org/10.1016/j.palaeo.2010.07.006

Jabbour, F., Craene, L. R. D., Nadot, S., \& Damerval, C. (2009). Establishment of zygomorphy on an ontogenic spiral and evolution of perianth in the tribe Delphinieae (Ranunculaceae). Annals of Botany, 104, 809-822. https://doi.org/10.1093/aob/mcp162

Jabbour, F., \& Renner, S. S. (2011a). Consolida and Aconitella are an annual clade of Delphinium (Ranunculaceae) that diversified in the Mediterranean basin and the Irano-Turanian region. Taxon, 60, 1029-1040. https://doi.org/10.1002/tax.604007

Jabbour, F., \& Renner, S. S. (2011b). A phylogeny of Delphinieae (Ranunculaceae) shows that Aconitum is nested within Delphinium and that the Late Miocene transitions to long life cycles in the Himalayas and Southwest China coincide with bursts in diversification. Molecular Phylogenetics and Evolution, 62, 928-942. https://doi.org/10.1016/j.ympev.2011.12.005

Joachimiak, A., Ilnicki, T., \& Mitka, J. (1999). Karyological studies on Aconitum lasiocarpum (Rchb.) Gayer (Ranunculaceae). Acta Biologica Cracoviensia, Series Botanica, 41, 205-211.

Joachimiak, A. J., Hasterok, R., Sliwinska, E., Musiał, K., \& Grabowska-Joachimiak, A. (2018). FISH-aimed karyotype analysis in Aconitum subgen. Aconitum reveals excessive rDNA sites in tetraploid taxa. Protoplasma, 255, 1363-1372. https://doi.org/10.1007/s00709018-1238-9

Johansson, J. T. (1995). A revised chloroplast DNA phylogeny of the Ranunculaceae. Plant Systematics and Evolution - Supplementa, 9, 253-261. https://doi.org/10.1007/978-37091-6612-3_25

Kadereit, J. W., Licht, W., \& Uhink, C. H. (2008). Asian relationships of the flora of the European Alps. Plant Ecology and Diversity, 1, 171-179. https://doi.org/10.1080/17550870802328751

Kadota, Y. (1981). A taxonomic study of Aconitum (Ranunculaceae) of the Akaishi Mountain Range in Central Japan. Bulletin of the National Museum of Nature and Science, Series B (Botany), 7, 91-112.

Kadota, Y. (1987). A revision of Aconitum subgenus Aconitum (Ranunculaceae) in East Asia. Sanwa Shoyaku Company.

Keener, C. S., Reveal, J. L., Dutton, E., \& Ziman, S. (1999). A list of suprageneric names in Ranunculaceae (Magnoliophyta). Taxon, 48, 497-506. https://doi.org/10.2307/1224562 
Kim, K. J., \& Jansen, K. J. (1998). A chloroplast DNA phylogeny of lilacs (Syringa, Oleaceae): Plastome groups show a strong correlation with crossing groups. American Journal of Botany, 85, 1338-1351. https://doi.org/10.2307/2446643

Kita, Y., \& Ito, M. (2000). Nuclear ribosomal ITS sequences and phylogeny of East Asian Aconitum subgen. Aconitum (Ranunculaceae), with special reference to extensive polymorphism in individual plants. Plant Systematics and Evolution, 225, 1-13. https://doi.org/10.1007/BF00985455

Kita, Y., Ueda, K., \& Kadota, Y. (1995). Molecular phylogeny and evolution of the Asian Aconitum subgen. Aconitum (Ranunculaceae). Journal of Plant Research, 108, 429-442. https://doi.org/10.1007/BF02344231

Krzakowa, M., \& Szweykowski, J. (1976). A natural hybrid between two different Aconitum species (Ranunculaceae, Dicotyledoneae) from the Tatry Mountains. Bulletin de L'Academie Polonaise des Sciences, Série des Sciences Biologiques, 25, 223-225.

Kyrkou, I., Iriondo, J. M., \& García-Fernández, A. (2015). A glacial survivor of the alpine Mediterranean region: Phylogenetic and phylogeographic insights into Silene ciliata Pourr. (Caryophyllaceae). PeerJ, 3, Article e1193. https://doi.org/10.7717/peerj.1193

Landis, J. B., Soltis, D. E., Li, Z., Marx, H. E., Barker, M. S., Tank, D. C., \& Soltis, P. S. (2018). Impact on whole-genome duplication events on diversification rates in angiosperms. American Journal of Botany, 105, 348-363. https://doi.org/10.1002/ajb2.1060

Leigh, J. W., \& Bryant, D. (2015). POPART: Full-feature software for haplotype network construction. Methods in Ecology and Evolution, 6, 1110-1116. https://doi.org/10.1111/2041-210X.12410

Liangqian, L., \& Kadota, Y. (2001). Aconitum L. In W. Zhyengi, P. H. Raven, \& H. Deyuan (Eds.), Flora of China. Caryophylaceae through Lardizabalaceae (Vol. 6, pp. 149-222). Science Press; Missouri Botanical Garden.

Луферов [Luferov], А. Н. [А. N.]. (2000). Конспект кавказских видов Aconitum (Ranunculaceae) [A synopsis of the Caucasian species of Aconitum (Ranunculaceae)]. Ботанический журнал [Botanicheskii Zhurnal], 85, 87-96.

Luo, Y., Zhang, F., \& Yang, Q. E. (2005). Phylogeny of Aconitum subgenus Aconitum (Ranunculaceae) inferred from ITS sequences. Plant Systematics and Evolution, 252, 11-25. https://doi.org/10.1007/s00606-004-0257-5

Maharramova, E. H., Safarov, H. M., Kozlowski, G., Borsch, T., \& Muller, L. A. (2015). Analysis of nuclear microsatellites reveals differentiation between Colchic and Hyrcanian populations of the wind-pollinated relict tree Zelkova carpinifolia (Ulmaceae). American Journal of Botany, 102, 119-128. https://doi.org/10.3732/ajb.1400370

Mai, D. H. (1995). Tertiäre Vegetationsgeschichte Europas [Tertiary vegetation history of Europe]. G. Fischer.

Médail, F., \& Diadema, K. (2009). Glacial refugia influence plant diversity patterns in the Mediterranean Basin. Journal of Biogeography, 36, 1333-1345. https://doi.org/10.1111/j.1365-2699.2008.02051.x

Mitka, J. (2000). Systematyka Aconitum subgen. Aconitum w Karpatach Wschodnich [Systematics of Aconitum subgen. Aconitum in the Eastern Carpathians]. Roczniki Bieszczadzkie, 9, 79-116.

Mitka, J. (2002). Phenetic and geographic pattern of Aconitum sect. Napellus (Ranunculaceae) in the Eastern Carpathians - A numerical approach. Acta Societatis Botanicorum Poloniae, 71, 35-48. https://doi.org/10.5586/asbp.2002.005

Mitka, J. (2003). The genus Aconitum in Poland and adjacent countries - A phenetic-geographic $s t u d y$. Institute of Botany, Jagiellonian University.

Mitka, J., Binkiewicz, B., Stachurska-Swakoń, A., Novikov, A., \& Rottensteiner, W. (2017). A synopsis of the genus Aconitum subgen. Aconitum in Europe. Studia Universitatis Babeş-Bolyai, 2017(Special issue), 166-167.

Mitka, J., Boron, P., Novikoff, A., Wróblewska, A., \& Binkiewicz, B. (2016). Two major groups of chloroplast DNA haplotypes in diploid and tetraploid Aconitum subgen. Aconitum (Ranunculaceae) in the Carpathians. Modern Phytomorphology, 9(Suppl.), 5-15. https://doi.org/10.5281/zenodo.159700

Mitka, J., Boroń, P., Wróblewska, A., \& Bąba, W. (2015). AFLP analysis reveals infraspecific phylogenetic relationships and population genetic structure of two species of Aconitum in Central Europe. Acta Societatis Botanicorum Poloniae, 84, 267-276. https://doi.org/10.5586/asbp.2015.012

Mitka, J., \& Starmühler, W. (2000). Phenetic variability of Aconitum lasiocarpum (Rchb.) Gáyer (Ranunculaceae): Extension of taxonomic and geographic borders. Acta Societatis Botanicorum Poloniae, 69, 145-155. https://doi.org/10.5586/asbp.2000.020 
Mitka, J., Sutkowska, A., Ilnicki, T., \& Joachimiak, A. (2007). Reticulate evolution of highalpine Aconitum (Ranunculaceae) in the Eastern Sudetes and Western Carpathians (Central Europe). Acta Biologica Cracoviensia, Series Botanica, 49, 15-26.

Mucher, W. (1991). Der Bunte Eisenhut, Aconitum variegatum L. (Ranunculaceae), in der Steiermark [Aconitum variegatum L. (Ranunculaceae) in Styria]. Mitteilungen des Naturwissenschaftlichen Vereines für Steiermark, 121, 195-198.

Novikoff, A., \& Mitka, J. (2011). Taxonomy and ecology of the genus Aconitum in the Ukrainian Carpathians. Wulfenia, 18, 37-61.

Novikoff, A., \& Mitka, J. (2015). Anatomy of stem-node-leaf continuum in Aconitum (Ranunculaceae) in the Eastern Carpathians. Nordic Journal of Botany, 33, 633-640. https://doi.org/10.1111/njb.00893

Novikoff, A. V., Mitka, J., Kuzyarin, A., Orlov, O., \& Ragulina, M. (2016). Some notes on the genus Aconitum in Chornohora Mts. Modern Phytomorphology, 9(Suppl.), 35-73. https://doi.org/10.5281/zenodo.159703

Ozenda, P. (2009). On the genesis of the plant population in the Alps: New or critical aspects Comptes Rendus Biologies, 332, 1092-1103. https://doi.org/10.1016/j.crvi.2009.09.018

Park, S., An, B., \& Park, S. (2020). Recurrent gene duplication in the angiosperm tribe Delphinieae (Ranunculaceae) inferred from intracellular gene transfer events and heteroplasmic mutations in the plastid matK gene. Scientific Reports, 10, Article 2720. https://doi.org/10.1038/s41598-020-59547-6

Pauli, H., Gottfried, M., Dirnböck, T., Dullinger, S., \& Grabherr, G. (2003). Assessing the long-term dynamics of endemic plants at summit habitats. In L. Nagy, G. Grabherr, C. Körner, \& D. B. A. Thompson (Eds.), Alpine biodiversity in Europe (pp. 195-207). Springer. https://doi.org/10.1007/978-3-642-18967-8_9

Paun, O., Lechnebach, C., Johansson, J. T., Lockhart, P., \& Hörandl, E. (2005). Phylogenetic relationships and biogeography of Ranunculus and allied genera (Ranunculaceae) in the Mediterranean region and in the European Alpine System. Taxon, 54, 911-930. https://doi.org/10.2307/25065478

Pawłowski, B. (1929). Elementy geograficzne i pochodzenie flory tatrzańskiego piętra turniowego [Geographical elements and the origins of the Tatra's high-alpine flora]. Rozprawy Wydziału Matematyczno-Przyrodniczego, Dział B, 68, 1-71.

Pearson, P. N., \& Palmer, M. R. (2000). Atmospheric carbon dioxide concentrations over the past 60 million years. Nature, 406, 695-699. https://doi.org/10.1038/35021000

Попов [Popov], М. Г. [М. G.]. (1983). Филогения. Флорогенетика. Флорография. Систематика [Phylogeny, florogenetics, florography, systematics]. Наукова думка [Naukova Dumka].

Posada, D., \& Crandall, K. A. (1998). Modeltest: Testing the model of DNA substitution. Bioinformatics, 14, 817-818. https://doi.org/10.1093/bioinformatics/14.9.817

Rambaut, A. (2016). FigTree v.1.4.3 [Computer software]. GitHub. https://github.com/ rambaut/figtree/releases

Rambaut, A., Lam, T. T., Carvalho, L. M., \& Pybus, O. G. (2016). Exploring the temporal structure of heterochronous sequences using TempEst. Virus Evolution, 2(1), Article vew007. https://doi.org/10.1093/ve/vew007

Rambaut, A., Suchard, M. A., Xie, D., \& Drummond, A. J. (2014). Tracer, version 1.6 [Computer software]. http://beast.bio.ed.ac.uk/Tracer/

Rannala, B., \& Yang, Z. (1996). Probability distribution of molecular evolutionary trees: A new method of phylogenetic inference. Journal of Molecular Evolution, 43, 304-311. https://doi.org/10.1007/BF02338839

Reichenbach, H. G. L. (1819). Uebersicht der Gattung Aconitum [Overview of the genus Aconitum]. Regensburg.

Ronikier, M. (2011). Biogeography of high-mountain plants in the Carpathians: An emerging phylogeographical perspective. Taxon, 60, 373-389. https://doi.org/10.1002/tax.602008

Ronquist, F., Huelsenbeck, J. P., \& Mark, P. (2005). MrBayes 3.1 manual. University of California.

Sang, T., Crawford, D. J., \& Stuessy, T. F. (1995). Documentation of reticulate evolution in peonies (Paeonia) using internal transcribed spacer sequences of nuclear ribosomal DNA: Implications for biogeography and concerted evolution. Proceedings of the National Academy of Sciences of the United States of America, 92(15), 6813-6817. https://doi.org/10.1073/pnas.92.15.6813

Schmitt, T. (2009). Biogeographical and evolutionary importance of the European high mountain systems. Frontiers in Zoology, 6, Article 9. https://doi.org/10.1186/17429994-6-9

Seitz, W. (1969). Die Taxonomie der Aconitum napellus-Gruppe in Europa [The taxonomy of the Aconitum napellus group in Europe]. Feddes Repertorium, 80, 1-76. https://doi.org/10.1002/fedr.19690800102 
Seitz, W., Zinsmeister, H. D., \& Abicht, M. (1972). Beitrag zur Systematik der Gattung Aconitum in Europe [Contribution to the systematics of the genus Aconitum in Europe]. Botanische Jahrbücher fur Systematik, Pflanzengeschichte und Pflanzengeographie, 92, 490-507.

Shaw, J., Lickey, E. B., Schilling, E. E., \& Small, R. L. (2007). Comparison of whole chloroplast genome sequences to choose non-coding regions for phylogenetic studies in angiosperms: The tortoise and the hare III. American Journal of Botany, 94, 275-288. https://doi.org/10.3732/ajb.94.3.275

Simon, J., Bosch, M., Molero, J., \& Blanché, C. (1999). A conspect of chromosome numbers in tribe Delphinieae (Ranunculaceae). Universitat de Barcelona Digital Repository. http:// hdl.handle.net/2445/95875

Soltis, P., \& Soltis, D. E. (2000). The role of genetic and genomic attributes in the success of polyploids. Proceedings of the National Academy of Sciences of the United States of America, 97(13), 7051-7057. https://doi.org/10.1073/pnas.97.13.7051

Song, J., Chen, J. J., Wang, M., Chen, Y. Y., \& Cui, B. K. (2016). Phylogeny and biogeography of the remarkable genus Bondarzewia (Basidiomycota, Russulaes). Scientific Reports, 6, Article 34568. https://doi.org/10.1038/srep34568

Stachurska-Swakoń, A., Cieślak, E., \& Ronikier, M. (2013). Phylogeography of a subalpine tall-herb Ranunculus platanifolius (Ranunculaceae) reveals two main genetic lineages in the European mountains. Botanical Journal of the Linnean Society, 171, 413-428. https://doi.org/10.1111/j.1095-8339.2012.01323.x

Starmühler, W. (1996). Systematics and chorology of the genus Aconitum in the Bela krajina region (Slovenia). Hladnikia, 6, 5-16.

Starmühler, W. (2001). Die Gattung Aconitum in Bayern [The genus Aconitum in Bavaria]. Berichte der Bayerischen Botanischen Gesellschaft zur Erforschung der Heimischen Flora, $71,99-118$.

Starmühler, W., \& Mitka, J. (2001). Systematics and chorology of Aconitum sect. Napellus and its hybrids in the Northern Carpathians and Forest Carpathians. Thaiszia - Journal of Botany, 10, 115-136.

Stebbins, G. L. (1984). Polyploidy and the distribution of the arctic-alpine flora: New evidence and a new approach. Botanica Helvetica, 94, 1-13. https://doi.org/10.5169/seals-65859

Stevens, P. F. (2001). Angiosperm Phylogeny Website. Version 14, July 2017. https://www.mobot .org/MOBOT/research/APweb/

Stuchlik, L., \& Shatilova, I. I. (1987). Palynological study of neogene deposits of southern Poland and western Georgia. Acta Palaeobotanica, 27, 21-52.

Surina, B., Pfanzelt, S., Einzmann, H. J. R., \& Albach, D. C. (2014). Bridging the Alps and the Middle East: Evolution, phylogeny and systematics of the genus Wulfenia (Plantaginaceae). Taxon, 63, 843-858. https://doi.org/10.12705/634.18

Sutkowska, A., Boron, P., \& Mitka, J. (2013). Natural hybrid zone of Aconitum species in the Western Carpathians: Linnaean taxonomy and ISSR fingerprinting. Acta Biologica Cracoviensia, Series Botanica, 55, 114-126. https://doi.org/10.2478/abcsb-2013-00015

Sutkowska, A., Boroń, P., Warzecha, T., Dębowski, J., \& Mitka, J. (2017). Hybridization and introgression among three Aconitum (Ranunculaceae) species of different ploidy levels in the Tatra Mountains (Western Carpathians). Plant Species Biology, 32(4), 292-303. https://doi.org/10.1111/1442-1984.12162

Sutkowska, A., Warzecha, T., \& Mitka, J. (2017). Genetic variation of Aconitum sect. Aconitum at a macrogeographical scale in the Carpathians. Polish Journal of Ecology, 65, 57-68. https://doi.org/10.3161/15052249PJE2017.65.1.006

Swofford, D. L. (2002). PAUP*. Phylogenetic analysis using parsimony (*and other methods). Sinauer Associates.

Tamura, K., Stecher, G., Peterson, D., Filipski, A., \& Kumar, S. (2013). MEGA6: Molecular evolutionary genetics analysis version 6.0. Molecular Biology and Evolution, 30, 2725-2729. https://doi.org/10.1093/molbev/mst197

Tamura, M. (1993). Ranunculaceae. In K. Kubitzky (Ed.), The families and genera of vascular plants. 2. Flowering plants. Dicotyledons. Magnoliid, Hamamelid and Caryophyllid families (pp. 563-583). Springer. https://doi.org/10.1007/978-3-662-02899-5_67

Tank, D. C., Eastman, J. M., Pennell, M. W., Soltis, P. S., Soltis, D. E., Hinchliff, C. E., Brown, J. W., Sessa, E. B., \& Harmon, L. J. (2015). Nested radiations and the pulse of angiosperm diversification: Increased diversification rates often follow whole genome duplications. New Phytologist, 207, 454-467. https://doi.org/10.1111/nph.13491

Thompson, J. D., Higgins, D. G., \& Gibson, T. J. (1994). CLUSTAL W: Improving the sensitivity of progressive multiple sequence alignment through sequence weighting, position specific gap penalties and weight matrix choice. Nucleic Acids Research, 22, 4673-4680. https://doi.org/10.1093/nar/22.22.4673 
Turland, N. J., \& Barrie, F. R. (2001). Family name listings modified in Appendix IB of the Saint Louis Code. Taxon, 50, 897-903. https://doi.org/10.2307/1223721

Tutin, T. G., Burges, N. A., Chater, A. O., Edmondson, J. R., Heywood, V. H., Moore, D. M., Valentine, D. H., Walters, S. M., \& Webb, D. A. (Eds.). (1993). Flora Europaea. Vol. 1: Psilotaceae to Plantanaceae (2nd ed.). Cambridge University Press.

Utelli, A. B., Roy, B. A., \& Baltisberger, M. (2000). Molecular and morphological analyses of European Aconitum species (Ranunculaceae). Plant Systematics and Evolution, 224, 195-212. https://doi.org/10.1007/BF00986343

Väre, H., Lampinen, R., Humphries, C., \& Williams, P. (2003). Taxonomic diversity of vascular plants in the European alpine areas. In L. Nagy, G. Grabherr, C. Körner, \& D. B. A. Thompson (Eds.), Alpine biodiversity in Europe (pp. 133-148). Springer. https://doi.org/10.1007/978-3-642-18967-8_5

Verlaque, R., Médail, F., Quézel, P., \& Babinot, J. F. (1997). Endémisme végetal et paléogéographie dans le Bassin Méditerranéen [Plant endemism and palaeogeography in the Mediterranean Basin]. Geobios, 21, 159-166. https://doi.org/10.1016/S00166995(97)80083-6

Volkova, P. A., Burlakov, Y. A., \& Schanzer, I. A. (2020). Genetic variability of Prunus padus L. (Rosaceae) elaborates "a new Eurasian phylogeographical paradigm". Plant Systematics and Evolution, 306, Article 1. https://doi.org/10.1007/s00606-020-01644-0

Wacławska-Ćwiertnia, K., \& Mitka, J. (2016). Typification of Zapałowicz's names in Aconitum section Aconitum. PhytoKeys, 58, 119-126. https://doi.org/10.3897/phytokeys.58.7110

Wang, L., Abbott, R. J., Zheng, W., Chen, P., Wang, Y., \& Liu, J. (2009). History and evolution of alpine plants endemic to Qinghai-Tibetan Plateau: Aconitum gymnandrum (Ranunculaceae). Molecular Ecology, 18, 709-721. https://doi.org/10.1111/j.1365294X.2008.04055.x

Wang, W., Dilcher, D. L., Sun, G., Wang, H. S., \& Chen, Z. D. (2016). Accelerated evolution of early angiosperms: Evidence from ranunculalean phylogeny by integrating living and fossil data. Journal of Systematics and Evolution, 54, 336-341. https://doi.org/10.1111/jse.12090

Wang, W., Lu, A. M., Ren, Y., Endress, M. E., \& Chen, Z. D. (2009). Phylogeny and classification of Ranunculales: Evidence from four molecular loci and morphological data. Perspectives in Plant Ecology, Evolution and Systematics, 11(2), 81-110. https://doi.org/10.1016/j.ppees.2009.01.001

Wendel, J. F. (2015). The wondrous cycles of polyploidy in plants. American Journal of Botany, 102, 1753-1756. https://doi.org/10.3732/ajb.1500320

White, T. J., Bruns, T., Lee, S., \& Taylor, J. W. (1990). Amplification and direct sequencing of fungal ribosomal RNA genes for phylogenetics. In M. A. Innis, D. H. Gelfand, J. J. Sninsky, \& T. J. White (Eds.), PCR protocols: A guide to methods and applications (pp. 315-322). Academic Press. https://doi.org/10.1016/B978-0-12-372180-8.50042-1

Winkler, M., Tribsch, A., Schneeweiss, G. M., Brodbeck, S., Gugerli, F., Holderegger, R., Abbott, R. J., \& Schönswetter, P. (2012). Tales of unexpected: Phylogeography of the arctic-alpine model plant Saxifraga oppositifolia (Saxifragaceae) revisited. Molecular Ecology, 21, 4618-4630. https://doi.org/10.1111/j.1365-294X.2012.05705.X

Xiang, K. L., Aytaç, Z., Liu, Y., Espinosa, F., Jabbour, F., Byng, J. W., Zhang, C. F., Erst, A. S., \& Wang, W. (2017). Recircumscription of Delphinium subg. Delphinium (Ranunculaceae) and implications for its biogeography. Taxon, 66, 554-566. https://doi.org/10.12705/663.3

Zając, M., \& Zając, A. (2009). The geographical elements of native flora of Poland. Laboratory of Computer Chorology, Institute of Botany, Jagiellonian University.

Zhang, M. L., Sanderson, S. C., Sun, Y. X., Byalt, V. V., \& Hao, X. L. (2014). Tertiary montane origin of the Central Asian flora, evidence inferred from cpDNA sequences of Atraphaxis (Polygonaceae). Journal of Integrative Plant Biology, 56, 1125-1135. https://doi.org/10.1111/jipb.12226

Zieliński, R. (1982a). An electrophoretic and cytological study of hybridization between Aconitum napellus subsp. skerisorae $(2 n=32)$ and A. variegatum $(2 n=16)$. I. Electrophoretic evidence. Acta Societatis Botanicorum Poloniae, 51, 453-464. https://doi.org/10.5586/asbp.1982.042

Zieliński, R. (1982b). An electrophoretic and cytological study of hybridization between Aconitum napellus subsp. skerisorae $(2 n=32)$ and A. variegatum $(2 n=16)$. II. Cytological evidence. Acta Societatis Botanicorum Poloniae, 51, 465-471. https://doi.org/10.5586/asbp.1982.043 